University of Louisville

ThinkIR: The University of Louisville's Institutional Repository

Electronic Theses and Dissertations

$5-2017$

\title{
Moral time and homicide investigations.
}

David Stuart Lapsey Jr.

University of Louisville

Follow this and additional works at: https://ir.library.louisville.edu/etd

Part of the Criminology Commons, Criminology and Criminal Justice Commons, Domestic and Intimate Partner Violence Commons, Forensic Science and Technology Commons, Law and Society Commons, Legal Theory Commons, Social Control, Law, Crime, and Deviance Commons, and the Theory, Knowledge and Science Commons

\section{Recommended Citation}

Lapsey, David Stuart Jr., "Moral time and homicide investigations." (2017). Electronic Theses and Dissertations. Paper 2681.

https://doi.org/10.18297/etd/2681

This Master's Thesis is brought to you for free and open access by ThinkIR: The University of Louisville's Institutional Repository. It has been accepted for inclusion in Electronic Theses and Dissertations by an authorized administrator of ThinkIR: The University of Louisville's Institutional Repository. This title appears here courtesy of the author, who has retained all other copyrights. For more information, please contact thinkir@louisville.edu. 


\title{
MORAL TIME AND HOMICIDE INVESTIGATIONS
}

\author{
By \\ David Stuart Lapsey Jr. \\ B.A., Indiana University Southeast, 2015 \\ A Thesis \\ Submitted to the Faculty of the \\ College of Arts and Sciences of the University of Louisville \\ in Partial Fulfillment of the Requirements for the degree of
}

\author{
Master of Science \\ in Criminal Justice \\ Department of Criminal Justice \\ University of Louisville \\ Louisville, Kentucky
}

May 2017 

MORAL TIME AND HOMICIDE INVESTIGATIONS

By

David S. Lapsey Jr.

B.A., Indiana University Southeast

A Thesis Approved on

April 20, 2017

By the following Thesis Committee

Dr. Bradley Campbell

Dr. Justin Nix

Dr. Gennaro Vito

Dr. Brian Schaefer

Dr. George Higgins 


\section{DEDICATION}

This thesis is dedicated to my father, David Lapsey Sr., who has helped drive me and teach me the discipline needed to complete my goals. I would also like to thank my brothers, Jacob and Ben, my mom, Dana, and my girlfriend Taylor McClure for encouraging me to work hard. 


\section{ACKNOWLEDGEMENTS}

I would like to thank Dr. Brad Campbell for making this thesis possible, and giving me guidance, support and lessons needed to complete the project. He has been a great influence on me in all aspects, and look forward to assisting with him on current and future projects. Also, I want to thank Dr. Richard Tewksbury. He has been great in facilitating my academic great and been an excellent mentor. I owe a lot to them and hold them both in high regard. 


\section{ABSTRACT \\ MORAL TIME AND HOMICIDE INVESTIGATIONS \\ David Lapsey Jr.}

April 20, 2017

Previous literature explores the many dimensions of homicide investigations, including case and individual characteristics, evidence and investigative activities. However, little research delves into situational characteristics and their relationship to specific homicides, charge severity sought by prosecutors and sentence length given to homicide offenders. The current study sampled homicide cases $(\mathrm{N}=68)$ to gather baseline information and data regarding judicial outcomes. Donald Black's Theory of Moral Time (2011) is tested and utilized as the study's conceptual framework for the study's hypotheses. 


\section{TABLE OF CONTENTS}

\section{Page}

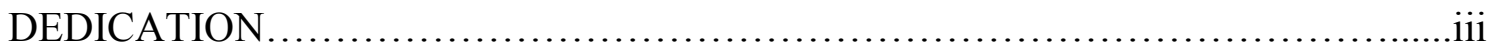

ACKNOWLEDGEMENTS..........................................................

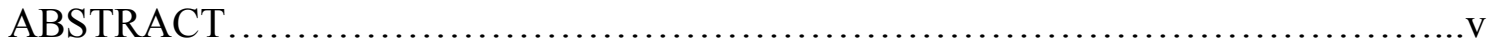

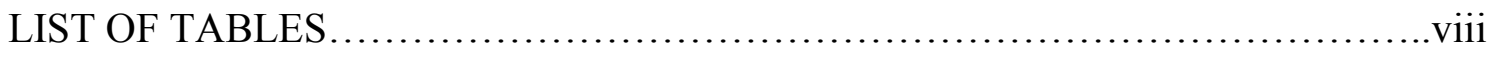

\section{CHAPTER}

I. INTRODUCTION: CRIMINAL JUSTICE FRAMEWORKS AND HOMICIDE

INVESTIGATIONS...........................................................

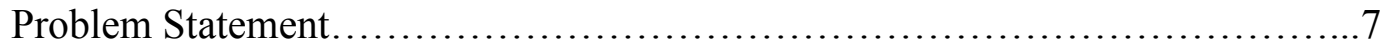

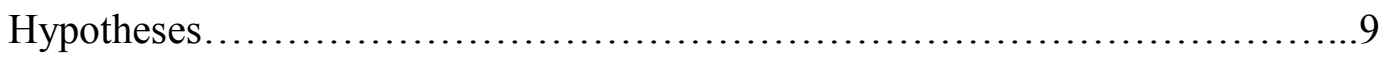

II. LITERATURE REVIEW ................................................... 12

Homicide Investigations............................................... 12

Situational Characteristics................................................ 14

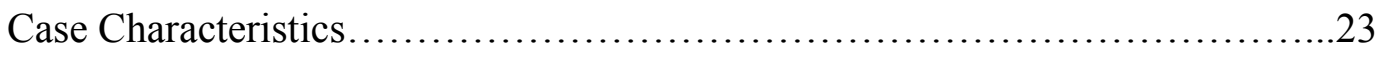

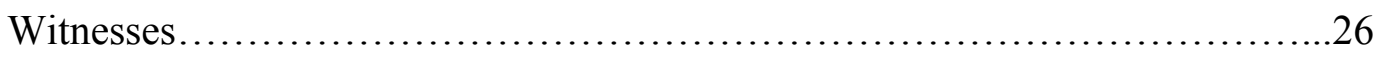

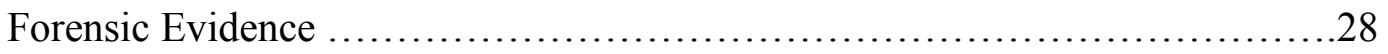

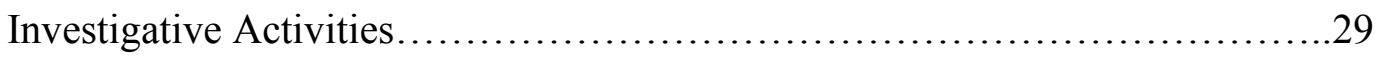

Theoretical Framework................................................... 31

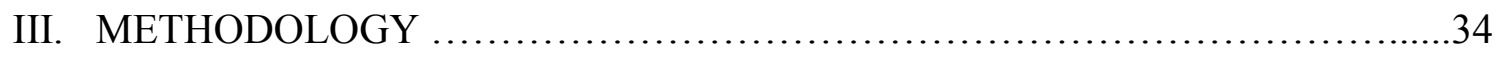

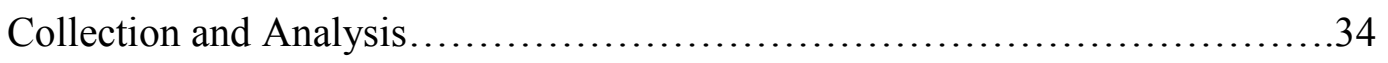


Data..................................................................

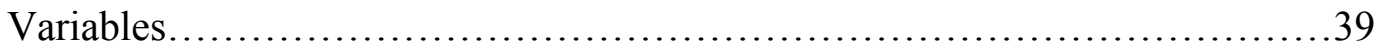

Analysis..........................................................41

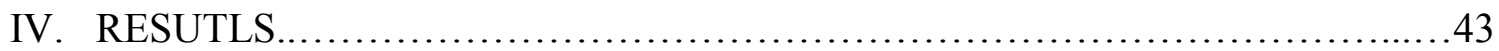

Frequencies.................................................. 43

Cross tabulation and Percent Comparison.................................. 48

V. DISCUSSION: INTRODUCTION ...................................53

Outcome Variables...................................................53

Evidentiary value..................................................... 57

Intimate Partner Homicides................................................58

Moral Time.........................................................6 60

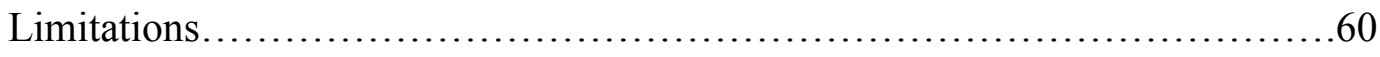

Summary of Current Study........................................6 61

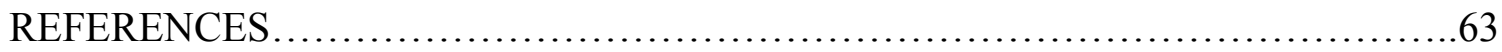

CURRICULUM VITA..................................................69 


\section{LIST OF TABLES}

Table

Page

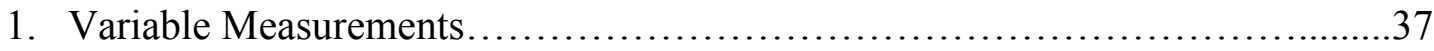

2. Frequencies of Primary Outcome Variables............................. 44

3. Frequency of Independent Variables....................................45

4. Cross tabulation for Sentence Length..................................48

5. Cross tabulation for Charge Severity .................................... 49

6. Cross tabulation for Victim/Offender Relationship........................50

7. Cross tabulation for Homicide Type..................................... 51 


\section{CHAPTER 1}

\section{INTRODUCTION}

\section{Criminal Justice Frameworks and Homicide Investigations}

Although research has paid significant attention to correlates of arrest in homicide investigations (Addington, 2006; Alderden \& Lavery, 2007), little is known about the impact of case, suspect, and victim characteristics on the severity of charges sought by law enforcement, and the relationship between these characteristics and the level of charges brought forth by prosecutors. Research into severity of charges brings necessary insights into the United States' justice system and what factors influences the decision making process. The majority of extant studies focus almost exclusively on offender characteristics (ex. race, gender, age) and the availability of evidence, and often ignore the relationship between the victim and the offender, such as a husband killing his wife or a son killing his father. For example, some perspectives, such as focal concerns focus on offender characteristics in relation to the level of "blameworthiness" attributed to offenders (Steffensmeier, Ulmer \& Kramer, 1998), and the impact of different types of evidence (e.g., forensic, eyewitness, etc.) on police and prosecutorial decisions, but less frequently on central situational characteristics, including victim and offender relationship.

Research has identified distinct variables that have been consistently correlated with homicide clearance rates, whether negatively or positively (Jarvis \& Regoeczi, 2009; Keel, Jarvis, \& Muirhead, 2009; Litwin \& Xu, 2007).). Specifically, these variables 
include the availability of forensic evidence (DNA evidence, fingerprints, ballistics etc.), case characteristics (location, weapon, time of day etc.), victim characteristics (gender, age, race etc.), suspect characteristics (gender, age, race etc.), investigative activities (staffing, management, analytical process employed etc.) and availability of witnesses. We know that of these characteristics, forensic evidence is not significantly associated with higher clearance rates, and that indoor locations, contact weapons, younger victims, white victims, availability of witnesses, and certain investigative activities are associated with higher clearance rates.

Scholars have demonstrated that the strongest correlate of clearance rate is intimate partner homicide (IPH) due to holding stronger evidentiary value compared to other cases (Roberts, 2007). These homicides differ due to their nature and surrounding social circumstances, because of the fact IPH are typically emotionally driven murders (Baskin \& Sommers, 2010; Cardarelli \& Cavanagh, 1992). Due to the circumstances of IPH, the offender is known to law enforcement and thus easier to investigate. Often, since women are at heightened risks of being killed by an intimate partner (Cooper \& Smith, 2011), the partner is the first and primary person of interest to law enforcement, allowing investigators to quickly identify and investigate the potential offender. This is not always the case, but law enforcement is cognizant to eliminate the most likely suspects to the homicide.

Scholars have extensively examined correlates of two distinct clearance options when clearing homicide cases (Jarvis \& Regoeczi, 2009). The traditional option is to clear a case by arrest. The second option, exceptional clearance, occurs when circumstances prohibit law enforcement from arresting, charging and prosecuting the suspect (Riedel \& 
Boulahanis, 2007). An exceptional clearance may occur if the suspect cannot be arrested, charged or convicted. Exceptional clearances are common in IPH cases, largely because IPH are more likely to result in murder-suicide, or prone to be justifiable homicide when the homicide is regarded as a non-criminal homicide under law and viewed without guilt (Banks, Crandall, Skylar \& Bauer, 2008).

Both murder-suicide and justifiable homicide are instances when the offender is known, but the outcomes fail to result in arrest, charge or prosecution. Although these cases do not meet the conventional criterion as a cleared case, such instances would result in an exceptional clearance. In order for law enforcement agencies to clear a case by exceptional means, the agency must meet the four following conditions: (1) identified the offender, (2) gathered enough evidence to support an arrest, make a charge and turn over the offender to the court for prosecution, (3) identified the offender's exact location so that the suspect could be taken into custody immediately, and (4) encountered a circumstance outside the control of law enforcement that prohibits the agency from arresting, charging and prosecuting the offender (Offenses Cleared, 2010). Often times, clearances and exceptional clearances are treated as one in the same, which may inflate an agency's overall clearance rate (Jarvis \& Regoeczi, 2009).

Several scholars have sought to explain how criminal justice practitioners come to make decisions in homicide cases (Englich, Mussmeiler, \& Strack, 2006; Spohn, Beichner, \& Davis-Frenzel, 2001; Steffensmeier, Ulmer, \& Kramer, 1998). The literature highlighting specific correlates of the causes of homicide is expansive, and some have applied criminological theories to provide context to these findings (Keel, Jarvis, \& Muirhead; Pratt \& Godsey, 2002). In the policing literature, however, there is less 
application of theory. Yet these studies are largely atheoretical, and relevant theories regarding practitioner decision-making have rarely been tested in the criminological literature. Such theories include Social Support (Pratt \& Godsey, 2002) and Victim Precipitated Criminal Homicide (Wolfgang, 1957). This is also true for Donald Black's (2011) Moral Time and update of his original theory the behavior of law-where he develops the theory of moral Time. The theory of moral time (2011) examines decisions making points for law enforcement and elaborates on these decisions using a pure sociological theory. The theory has limited testing, especially when looking at decisionmaking points for IPH. Unlike previously mentioned theories, moral time (2011) contends that police decision-making is greatly influenced by degrees of intimacy, inequality, or diversity between people and groups. For IPH, Black measures intimacy between victims and offenders.

The theory of moral time (2011) is explained through social space and social time, which are conceptualized as dynamic elements in the theory. Social space is the geometry of social reality and social time is the dynamic dimension of social space between individuals measured through intimacy. Black explains, "Social space constantly fluctuates, and every fluctuation is a movement of social time" (p. 4). Meaning, social space contains relationships between individuals and the intimacy between the individuals is in constant flux and movements. Furthermore, the fundamental cause of conflict is the movement of social time, and "every conflict is itself a movement of social time and every conflict therefore causes more conflict" (p. 4). Social space, again, is multidimensional and features relational distance as the degree of intimacy (the degree of intimacy between one person or groups in the life of another), vertical distance as the 
degree of inequality (wealth or authority), and cultural distance as the degree of diversity (religion or ethnicity). Closeness of social space differs considerably from that of physical space, and closeness in social space may differ from A-B and B-A, whereas in physical distance A-B is the same distance from B-A. Black elaborates further and explains social time through relational time, vertical time and cultural time. For the current study's purpose, relational distance and relational time are applied to analyze police decisions in IPH cases (Black, 2011).

Interestingly, it is possible that homicides with the greatest effect on social space, IPH, may present a paradox in Black's assertions in moral time. Specifically, IPH cases may be associated with a higher likelihood for clearance, but might result in less severe charges and shorter sentence lengths, when compared to stranger homicides. It is possible homicides with greater effect on social space will have a longer, intensified growth of conflict (Jensen, 2001), and in the growth process, accumulate more witnesses. In the culmination of the most intimate conflict, IPH, there will be greater potential for evidence. This is simply due to the nature and situational characteristics of the homicide type. These characteristics include evidence known for strong evidentiary value such occurring indoors, contact weapons, and readily available suspect (Alderden \& Lavery, 2007; Roberts, 2007).

IPH cases are associated with factors that have consistently resulted in homicide case clearances - use of contact weapons (e.g., hands, feet, blunt object, or by means of strangulation), indoor locations, witnesses—-forming stronger evidence that subsequently increase the odds of case clearance (Roberts, 2007). These homicides incubate solvability factors based solely on their nature. For instance, Alderden and Lavery (2007) 
classify expressive homicides as having the primary motive to harm the victim, and discovered all other homicides are less likely to be cleared due to the offender/victim not knowing each other and having prior relations. Quinet and Nunn (2015) noted that $62 \%$ of IPH cases were solved in two days or less, the highest among all homicide types.

In sum, the relationship between the homicide type and clearance predictors seems clear. Specific homicide types inherently carry strong predictors of homicide clearance. IPH has the highest clearance rate among all homicide types when comparing the case evidence involved (Alderden \& Lavery, 2007; Litwin \& Xu, 2007; Regoeczi, Jarvis, Riedel, 2008; Roberts, 2007), and homicides with witnesses and known motives also have high clearances rates (Baskins \& Sommers, 2010; Litwin \& Xu, 2007; Regoeczi, Jarvis, Riedel, 2008; Schroeder and White, 2009). It follows that there is a connection between homicide type, significant clearance predictors, and high clearance rates. IPH typically contains evidence associated with the highest clearance rates, thus IPH is the highest cleared cases when comparing different situational homicides that are driving for personal gain or motivated by other felony crimes (i.e. concomitant felonies, instrumental homicides). What is less clear, however, is how severe law enforcement perceives these cases in comparison to other types of homicides. Specifically, research has not examined the severity of charges initially sought by law enforcement officers, and how victimoffender relationships play into this decision.

The situational characteristics from homicide cases determine the potential available evidence and its evidentiary value. IPH are solved relatively easily and with greater success due to the increased probability of high evidentiary value stemming from the situational characteristics involved. In many cases, it is the innate evidence generally 
correlated to homicide cases that facilitate case clearances, rather than forensic evidence or other investigative tools. What enables the increased ability to solve IPH is the connection with clearance predictors of higher evidentiary value, which constitutes evidence as the highest clearance rates.

\section{Problem Statement}

Present literature provides little information regarding the adjudication of IPH defendants and the comparison of IPH against other homicides types (Auerhahn, 2007). Studies focus efforts towards individualistic approaches when researching sentencing outcomes and fail to examine situational aspects of homicides and how these aspects affect charging decisions (Koons-Witt, Sevigny, Burrow, \& Hester; Spohn \& Cederblom, 1990; Stout \& Brown, 1995). By doing so, prior studies are unable to account for a host of characteristics involved with the homicide which restricts our scope of knowledge regarding how serious law enforcement considers IPH cases. The present study contributes to the literature by examining the relationship between case, victim, and suspect characteristics on the charges sought by law enforcement in homicide cases. The study advances the literature by providing a nuanced understanding of the severity of cases perceived by law enforcement.

Literature provides inconsistent results in regard to offender characteristics, charge severity and sentence lengths. Gender and race are common variable used when studying adjudications and little support is available to provide a true conclusion for their affects within the adjudication process (Spohn, 1990; Steffensmeier, Ulmer, \& Kramer, 1998). Research has demonstrated a strong correlation between younger, black male offenders and longer sentences for the black male offenders compared to whites, but no disparities 
with females and Hispanic offenders (Demuth \& Steffensmeier, 2004; Steffensmeier, Ulmer, \& Kramer, 1998; Stout \& Brown). Spohn and Cederblom (1991) concluded sentence disparities only occurred during less serious offenses and race was not considered a significant factor at the sentencing stage; however, seriousness and suspects' prior criminal record remained significant predictors of charge severity.

Several studies have focused on solvability factors and investigation techniques associated with homicides (Carter \& Carter, 2015; Keel, Jarvis, \& Muirhead; Wellford \& Cronin, 2000), however, there is less discourse involving the nature of particular homicides and the inherent evidence available to IPH. Furthermore, greater explanation needs to be directed towards IPH and testing and measuring results from the adjudication process.

Predictably, homicides with no available motive or witnesses are less likely to be solved than those with a known motive (Baskins \& Sommers, 2010; Litwin \& Xu, 2007; Regoeczi, Jarvis, Riedel, 2008). Unavailability of motive holds a strong connection with witnesses to the homicide. This is due to possible witnesses coming forth to explain the motive to investigators. If only the suspect and defendant were knowledgeable of the homicide, then a suspect may only produce a motive. Expressive homicides have highest clearance rates and homicides with witnesses have high clearances rates, so it is logical to assume a connection between them.

The link between motive, witnesses, and sentencing outcomes for homicides needs greater exploration, and Donald Black's theory of moral time (2011) provides a sound theoretical framework to examine these issues. Intimate Partner Homicide cases appear to have the highest clearance rates and greatest evidentiary value, which should make for 
strongest court cases. But if Black's theory is correct, then IPH will correlate with lesser charges and shorter sentences.

\section{Hypotheses}

IPH cases will be easier to solve than instrumental homicides motivated by reasons other than intimate partner related. This is due to the evidence generally associated with IPH. Intimate partner homicide is linked to the highest clearance rates, associated with higher numbers of clearance predictors, and involves a greater deal of intimacy; levels of intimacy are dependent on the homicide's victim/offender relationship. Greater intimacy levels are associated with greater knowledge of motive and witness availability for investigators. If the level of intimacy for the crime is high, then witnesses and motive will commonly be available. When this is the case, defendants are expected to experience lesser charges and shorter, lenient sentences.

While Donald Black's theory of moral time forecasts greater sentences for stranger homicides due to lower levels of intimacy, one might presume this false due to the many variables surrounding charging and sentencing decisions other than intimacy between the victim and offender. Instead, the author posits that non-stranger homicides will result in more severe charges being sought by law enforcement. This is due to greater likelihood for evidence stemming from non-stranger homicides and the potential for increase in charges with concomitant felonies homicides, rather than a single homicide charge.

Donald Black's (2011) theory of moral Time could provide valuable insight for homicide clearance rates and the nature within IPH. The intimacy level and movement social space determine homicide-sentencing outcomes. The greater social movement within social space caused by the homicide, the less social movement within social space 
enacted by the punishment. Furthermore, IPH are comparatively easy to solve, carrying larger numbers of valuable clearance predictors, but receive less severe criminal charges and sentence lengths.

Because the intimacy levels of homicides vary, so do the social movement they bring. For instance, an expressive homicide, such as a husband killing his wife, will be subjected to a less severe and shorter sentence. For this reason Black (2011) states, "If you send my father to prison for killing my mother, for instance, I lose not only my mother but also my father and whatever he contributes to my family and life" (p. 9). However, the IPH case is significantly more likely to contain greater evidentiary value (Baskins \& Sommer, 2010). This hypothesis is due to the high level of social movement brought by the IPH, "And because violence itself is often a radical and rapid movement of social time, violence often causes more violence" (Black, 2011, p. 9).

Due to the notion of conflict causing more conflict, there will have been a buildup of conflict leading to the homicide in IPH cases (Black, 2011; Jensen, 2001). Although witnesses may have not been on scene when the homicide occurred, there is a greater likelihood of people witnessing the events that escalated to a homicide. The fact that investigators have more witnesses grants investigators significantly more leads and potential motives for their case. No homicides involve greater intimacy than those involving family members or domestic partners. Therefore, expressive homicides, namely IPH, will have the greatest movement in social space, the highest clearance rate, and lesser charge severity and sentencing lengths when compared against instrumental and other homicide types.

The current study utilizes data gleaned from sixty-eight (68) closed homicide 
cases investigated by the Louisville Metropolitan Police Department. The data contain information concerning all subjects involved, as well as any witnesses or third parties. By collecting all relevant information, the researcher was able to collect data to inform a better understanding of the homicide and any actors involved. The data span from 2009 through early 2015 and were collected using a coding instrument conducive to collecting desired variables, which include suspect age, race, gender, criminal history, victimoffender social relationship, evidence collected and evidence processed (time and date), witnesses, charge(s), judicial outcome, sentence length etc. These variables, along with others from the 27-page instrument, work to measure and test the current hypotheses.

The project examines variables in the dataset to identify homicides with higher levels of intimacy, IPH and non-stranger, to have larger numbers of witnesses and valuable clearance predictors, but sanctioned with lesser charges and sentences; homicide type elicits case and sentencing outcomes. If true, this provides pronounced support for Donald Black's theory of moral time. The project seeks to accomplish the following two primary goals:

1. Assess Donald Black's theory of moral time, specifically Movements of Social Space in Relational Time by looking at offender punishment severity (charges and lengths).

2. Examine whether IPH and non-stranger cases result in less severe punishments sought by law enforcement and prosecutors, despite holding case characteristics known to be associated with higher clearance rates. 


\section{CHAPTER 2}

\section{LITERATURE REVIEW}

\section{Homicide Investigations}

Homicide clearance rates have been on a steady decline since the 1960's. Once estimated to be $90 \%$ in the 1960 's, current estimates have dropped to approximately $60 \%$ of cases cleared nationwide (Carter \& Carter, 2015; Schroeder \& White 2009). This is considerably low when compared to clearance rates in other countries, such as in Germany at 96\% and in Japan at 95\% (Roberts, 2007). Homicide clearance rates have trended downward similar to reductions in the prevalence of other violent crime (e.g., robbery, aggravated assault) that have also dropped over the past 40 years. It is now evident that the yearly number of homicides has been decreasing, but there remains a misconception that homicide investigators are overwhelmed by caseloads (Cooper \& Smith, 2011).

Although homicide clearance rates have declined, the public is generally unaware of the decline. A widespread misconception exists that homicide clearances are based on forensic evidence, particularly DNA, gunshot residue, ballistics information, or fingerprints, that the public believes is available in all cases, and makes investigative decisions much easier (Schroeder \& White, 2009). Surprisingly to most, however, forensic evidence typically affords minimal support in case clearance decisions and is more often used in judicial decisions, after the suspect has been identified and referred to prosecutors. Forensic evidence may build strong cases in court, but its utility during 
investigations is limited (Baskins \& Sommers, 2010; McEwen \& Regoeczi, 2011). For instance, Baskins and Sommers (2010) concluded that forensic evidence is an auxiliary and non-determinative for homicide case, and instead, cases were significantly more likely to result in arrest, referrals, and charges when a witness provided information to investigators. Forensic evidence works to keep pace with various homicide types and characteristics.

Homicide investigations have been characterized as dynamic; meaning, their nature and circumstances have changed dramatically throughout the years. The major homicide types and situational characteristics are seen within two primary types, which can be broken down into categories such as, instrumental and expressive (Alderden \& Lavery, 2007). Instrumental homicides occur when the offender is motivated by gain (i.e. monetary, material, or social), which incorporate robberies among other situations. Expressive homicides develop from emotionally stimulating confrontations, which include an offender killing a lover or a friend during a heated verbal exchange (Fox \& Allen, 2014). Expressive homicide incorporates IPH, which have the highest clearance rates among expressive and instrumental homicides, and is examined in-depth in the present study.

The higher rate of clearance for IPH cases has been attributed to the nature of these cases. For instance, perpetrators of IPH are more likely to utilize contact weapons (i.e. hands, feet or rope) during the act or have the act occur indoors, both of which have been associated with higher clearance rates in homicide investigations because these two characteristics increase the probability that physical evidence can be recovered and preserved (Addington, 2006; Alderden \& Lavery, 2007). It follows that since IPH often 
occur indoors, physical evidence will remain protected from outdoor elements that threaten to destroy or eradicate evidence. Also, homicides in which a motivation was disclosed increase clearance odds by 2.5 , which are also relatively easy to discover within IPH (Davis, Jensen, Burgette, \& Burnette, 2014). Quinet and Nunn (2014) developed a motivation typology to measure the clearance rates and occurrences for homicides $(\mathrm{N}-$ 221). Among the motivational types (i.e., argument/fight, domestic, drug related, gang related, noncriminal, other motive, revenge robbery/money and unknown), drug related (32.1\%), and unknown (29.9\%) were the most unsolved cases amid the typology. Furthermore, the authors reported only $0.9 \%$ of domestic motivated homicides remained unsolved.

\section{Situational Characteristics}

Manner of death. Discovering motive and manner of death is essential for understanding the homicide, and produces a course of action for interviewing suspects and witnesses. Each homicide type is different by nature and understanding their unique characteristics assists investigations (Carter \& Carter, 2011). Homicide investigators (particularly lead detectives) closely cooperating with medical examiners and attending autopsy is substantial to understanding the manner of death (Carter \& Carter, 2011), ultimately helping determine the direction of an investigation. However not all studies conclude this notion, and some research shows the opposite, displaying significantly negative impacts when investigators are present (Schroder \& White, 2009). The negative impact is potentially due to a "Whodunit" case investigation (Simons, 1991), where the detective is thirsty for any additional existing evidence. If it is necessary for investigators to attend the autopsy, then there is probably no clear manner of death at the crime scene. 
Often times consulting with medical examiners is unnecessary, and a motive and manner of death is apparent based upon evidence from the scene. Regardless of means and difficulty for identifying these fundamental aspects, the importance for accomplishing this is paramount to an investigation.

Motive. An essential key to successful homicide investigations is suspects' motive or the circumstances surrounding the event. Without a motive, investigations are at a statistically greater risk of remaining unsolved. Meaning, motive availability is often due to available witnesses and suspects to the homicide, and investigators are greatly disadvantaged when a motive is failed to be established. Homicide motive suggests what evidence is potentially available and directs the investigation's path. Once a motive is established, investigators may determine suspects and produce an insight into the circumstance.

Certain motives are readily exposed during the investigation, such those involving homicides of passion, robberies, or drug deals. Various murders yield various pieces of evidence, which can make identifying the motive simpler. Due to this, murder types maintain differing clearance rates, and past literature provides evidence for this notion (Litwin \& Xu, 2007; Maxfield, 1989). Several studies test and examine demographics, searching for patterns in data for characteristics such as race, age, and gender. Although besides younger victims, and commonly female victims, results are not as clear when assessing victim characteristics as clearance predictors. For instance, Roberts (2007) found no correlation between victim characteristics and clearance after controlling for situational characteristics. But, other authors find that, though results are inconsistent between studies, race, age and gender correlated to clearance outcomes. Female victims, 
younger and elderly victims, and white victims are more likely to be cleared (Litwin \& Xu, 2007; McEwen and Regoeczi, 2015; Jarvis \& Riedel, 2008).

Victim characteristics, such as gender, race and age, show support linking the demographics to clearance rates. Results for age and gender have remained fairly consistent concerning clearance rates; however, evidence disputing these finds is available. Studies often refute the correlating findings, suggesting an alternate answer for the link that is found within situational characteristics of homicides (Roberts, 2007).

Gender. McEwen and Regoeczi (2015), using logistic regression analysis from 294 homicide cases in Cleveland, Ohio from 2008-2011, found the odds of a case being cleared were 2.5 times higher when the victim was a female. These findings parallel with prior research on victim characteristics that show female victims experience a greater likelihood for clearances (Roberts, 2007). Regoezci, Jarvis, and Riedel (2008) used a different analysis by applying survival analysis. The separate method rendered similar results, and survival analysis through Cox proportional hazard models, displays an increased likelihood of clearance involving females. Alternatively, research has demonstrated an increased likelihood of clearance for male victims rather than females (Litwin \& Xu, 2007). There are discrepancies between studies; however, female victims are perhaps a clearance predictor due to the prominent risk of being victims of IPH (Cooper \& Smith, 2011).

Age. Younger victims are a strong predictor to clearance rates, and commonly result in shorter investigations (Litwin \& Xu, 2007; Regoeczi, Jarvis \& Riedel, 2008). Younger victims, specifically under 12 years old, are more likely to be cleared, possibly due to increased likelihood of IPH involvement (Roberts, 2007). This consistent evidence 
suggests younger victims are at a greater risk of becoming victims of IPH. Intimate partner homicide commonly occurs within the suspect or victims' residence, elevating the odds of the child being in the residence during the incident. Suspects of IPH are prone to murder suicide, elevating the potentially for the suspect to kill those within the home during the incident. Furthermore, the potential for familial abuse-specifically child abuse - is often greater for victims of IPH (Pritchard \& Butler, 2003). The defendants often perpetrate violence against the family prior to the homicide, and may decide to kill their children as well. Findings from US Department of Justice report "that most homicides of young children are committed by family members" (Finkelhor, Ormrod \& Humphrey, 2001), providing further evidence that child homicide victims are more likely to be victims of IPH than other homicide types.

Race. The majority of research finds that non-white victims experience lower clearance rates when compared to whites (Keel, Jarvis, \& Muirhead, 2009; Litwin \& Xu, 2007), and researchers McEwen and Regoeczi (2015) collected data from 2008-2011 and report the odds of clearance for whites to be 3.3 greater than non-whites. However, when studies control for time to clearance there is no significant impact by race and no victim devaluation based on victim's race (Regoeczi, Jarvis \& Riedel, 2008). Furthermore, studies appear to display that children, females, and whites are at an increased likelihood to be victims of homicides that are easier solved than other homicide types, circumstances include occurring indoors, involving contact weapons, and greater witness availability (Addington, 2006).

Uncovering a motive leads to discovering the surrounding case circumstances, and when this occurs, literature presents strong evidence for the case to become cleared 
(Litwin \& Xu, 2007). Certain case types are correlated with higher clearances, and potentially explains the reasons for particular demographics linked to higher case clearances. For instance, younger victims and female victims were often found to be associated with higher clearance rates. However, these victims are commonly related to $\mathrm{IPH}$, which is associated to higher clearance rates themselves. Therefore, the true correlation may lie within the homicide type, and not within the victim's demographics.

Using continuous Event History Analysis Clearance and hazard rates from Cox regression, Roberts (2007) found that the significant relationship between victim characteristics and clearance disappeared when controlling for situational characteristics. Further noting the importance of homicides' situational characteristics. When circumstances are unknown, cases are more likely to remain open longer and less likely to be cleared (Litwin \& Xu, 2007). This evidence is especially true when compared with circumstances resulting from arguments (Regoeczi, Jarvis, \& Riedel 2008), and is possibly caused from larger amounts of victims and suspects engaging in confrontations with familiar people.

Crime type, charge severity and sentence length. Charge and sentencing is examined on multiple levels in attempts to ensure fair punishment across all contexts of homicide cases. Research concerning sentencing is prevalent, but largely focuses on offender characteristics and decisions within the judicial process. The offender approach to examining sentencing focuses the attention to the individual, and resulting in the "blameworthiness" of that individual (Steffensmeier, Ulmer \& Kramer, 1998). However, little consideration is placed upon situational factors that possibly influence charges and sentencing. 
A study by McEwen and Regoeczi (2015) indicated charge severity and sentence length increased when forensic evidence was available for prosecutors. Charge severity and sentence length also increased when the offender was female, when offender was black, and when the case was a stranger homicide. Furthermore, sentence length was revealed to be longer if defendants declined a plea offer and instead took their case to trial (Auerhahn, 2007).

Victim/offender relationship. Discovering victim/offender relationships is significant to the investigation and helps to direct the investigation. "Findings consistently pointed to difficulties of processing homicide incidents when the victim and suspect were strangers" (Baskin \& Sommers, 2010, p. 1,154). Coinciding with motive is victim and offender relations. Knowing the relationship's dynamics is crucial to investigations, and potentially provides assistance to understanding motive. According to Roberts (2007) clearance hazard greatly increased during non-stranger cases. Incidents among family members increases hazard rates $85 \%$ greater than those involving strangers. When offenders and victims have an established relationship, detectives find themselves at an advantage to explore possible witnesses and gather information regarding the relationships, and possibly discover a motive within the dynamics of the homicide.

Dawson (2004), studying victim/offenders relations over a 22-year period, found that victim offender relationship has a significant impact on the processing of homicide cases. The author found charging decisions, type of adjudication and sentencing with IPH defendants influenced by the relationship. Furthermore, IPH offenders received lenient sentences at all three stages mentioned when compared to all other homicide types. 
Although courts granted leniency through those stages, no correlation between IPH and conviction was established.

This establishes further evidence that particular homicides are linked to stronger clearance predictors. Intimate partner homicide has the highest rates of clearance, and not surprisingly, will have information concerning offender and victim relationships. Victims of drug and gang-related activities are also more likely to know each other, and also increase odds of clearance (Roberts, 2007).

Concomitant homicides. Concomitant homicides transpire during the process of committing a felony crime. A majority of felony crimes are classified as instrumental, or when obtaining money or property is the offender's primary motive (Alderden \& Lavery, 2007). Often felony-related homicides are committed during robberies or drug deals. Results concerning felony-related homicides are varied, but a general consensus is drawn from research that finds concomitant homicides to increase odds of clearance (Roberts, 2007; Regoeczi, Jarvis, \& Riedel, 2008).

The study by Roberts (2007) found a significant $32 \%$ clearance hazard rate increase for concomitant, suggesting offenders are more likely to leave behind evidence due to multiple crimes being committed. This finding is both consistent and at odds with related studies regarding felony-related homicides by Regoeczi, Jarvis, and Riedel (2008). The authors examined clearance rates using survival analysis and discovered there was no significant relationship between clearance rates and felony-related homicides; however, using logistic regression the authors found significance between the two variables. This provides evidence that a greater level of difficulty is involved with felony-related homicides than previously thought. 
Unlike IPH where a greater knowledge of relationships and motive is available, concomitant homicides believed to be easier solved than most due to evidence trails left behind. An offender is not committing a single crime, but multiple in the homicide's course and creating added evidence.

Intimate/sexual partner/domestic. Evidence repeatedly suggests a connection between intimate partner, or expressive homicides, and higher clearances (Alderden \& Lavery, 2007; Jarvis \& Regoezci, 2009; Litwin \& Xu, 2007). This homicide category generally involves less forethought and happens during the heat of the moment or intense argument. These are always non-stranger homicide, which greatly increases odds for success. Characteristics, social circumstance and case outcomes diverge greatly from other homicides, and are correlated with high solvability factors. By their nature, IPH are quicker and easier to solve compared against other homicide types.

Details and incident characteristics of IPH are unique to homicide investigations. First, IPH always occur between victims/offenders that know each other and usually culminate due to high levels of intimacy between those involved. Second, differences in victims are fewer and females are more likely to be victims of IPH than any other homicide (Catalano, 2013; Jensen, 2001). Third, according to a national crime victimization survey from the Bureau of Justice Statistics, 39\% of 3,032 females were murdered by intimate partners compared to $3 \%$ of the 10,878 males murdered in 2010 by an intimate (Catalano, 2013).

Studies indicate IPH are sanctioned less punitively than their counterparts while also resulting in greater likelihood for receiving death sentences (Auerhahn, 2007; Dawson, 2004). Black (2011) provides explanation for the contrasting punishments. Intimate 
partner homicides involve long and short relationships, and length of intimate relations alter effects to social space. An IPH involving a shorter relationship between victim/offender with no children would expect to provoke increased punishments when compared to a longer relationship involving children from the victim/offender. This is due to the greater intimacy expected from spouses with children and the drastic movements in social space once a child has lost a parent.

Auerhahn (2007) compared 1137 cases of IPH and non-IPH during the period 19952000 in Philadelphia, and analyzed outcomes for defendants. The author noted no differences between race/ethnicity, victims were much more likely to be women and a gun was used at half the rate for IPH. Overall, intimate partner homicides are more likely to be convicted for the most and least serious homicide grades and sentenced to the most and least punitive sanctions. Meaning, the charge and sentence disparities for the sample were wide ranging, and either received the most lenient punishments or harshest punishments in the sample. There was a large standard deviation seen from the charges and sentences of IPH offenders.

Attention to adjudication for IPH is scarce, but few studies have explored their dynamics (Auerhahn, 2007; Catalano, 2013; Dawson, 2004). Research probes correlations among IPH and non-IPH as well as gender differences amid the studies. Results diverge when examining sentence lengths for IPH, but remain inconsistent when testing for gender. Stout and Brown (1995) concluded female defendants of IPH received harsher sentences than their male counterparts. The authors reported women at a $44 \%$ greater probability of receiving life sentences than males. No courts mandated a life sentence without the possibility of parole to a male, but females were sentenced for life 
without parole in $75 \%$ of cases (Stout \& Brown, 1995). However, recent studies produce evidence that contradict findings that men are granted lenient sentences (Auerhahn, 2007; Koons-Witt, Sevigny, Burrow \& Hester, 2014).

Literature indicates that not only are IPH criminal investigations dissimilar to other categories, but the adjudication process is too. Cases range from being most punitive and convictions for severest charges, and also for leniency in charges and sentencing. No other homicide category reveals this pattern. Explanations based from race/ethnicity and age does not appear relevant for findings; however, gender may play a role in disparities. Evidence for gender is conflicting and no decided answer is available.

\section{Case Characteristics}

Suspect criminal record. Identifying and collecting as much information as possible on suspects is regarded as highly important for homicide investigations (Carter \& Carter, 2011). As previously mentioned, research for race, gender, and age display varying affects for investigation outcomes. Furthermore, the criminal record of the suspect appears to be of evidentiary value. Clearance, for example, is significantly less likely when the victim has a criminal record (Schroeder \& White, 2009). Cook, Ludwig, and Braga (2005) report similar results, $42.6 \%$ of 884 cases had at least one felony conviction and $71.6 \%$ had experienced any arrest before the alleged homicide occurred. Results such as these likely stem from risks associated with lifestyles lived by the suspects (Wolfgang, 1957), which can be seen when examining the various homicide motives; a large portion of homicides are instrumental (drug/money disputes) or concomitant (occurring during other crimes). If many suspects are involved with homicides such as these, the suspects are likely engaging in other forms of crime prior to 
the murder. This point is especially true given that estimates place the odds of arrest at 1 in every 11,000 crimes (Maher and Dixon, 1999).

Weapon. Contact weapons including knives, hands, or blunt objects have higher clearance rates than other weapons. Findings associate noncontact weapons, such as firearms or poison, with lower clearance levels (Roberts, 2007; Baskins \& Sommers, 2010). A study by McEwen and Regoeczi (2015) reported 79.6\% clearance rate when knives were the murder weapons, significantly higher than the study's overall clearance rate of $61.9 \%$. Over half of these cases involved IPM. Prior research alludes to a greater probability of contact weapons used in IPH and increased chance of witnesses due to extra time necessary when a contact weapon in the homicide (Schroeder \& White, 2009).

Studies are consistent with findings concerning lower clearance rates for firearms (Litwin \& Xu, 2007). Interestingly, a study revealed firearms do not prolong length of time to clearance, but hands and feet did by $26 \%$ (Regoeczi, Jarvis \& Riedel, 2008). The lower increase is potential attributed a lack of physical evidence left by the suspect, or the ease at which a suspect may commit the murder and flee a scene. Firearms are increasingly more likely to be used in modern homicide.

Body location and area. Homicide clearance are consistently linked to locations where the victims' body was discovered. There is continual evidence that display cases occurring indoors, and especially occurring within a residence increases the likelihood for clearance (Litwin \& Xu, 2007; McEwen \& Regoeczi, 2015). Other research confirms this, and Regoeczi, Jarvis \& Riedel (2008), concluded nonresidential indoor, outdoor, and other locations showed less odds of clearance than residences. Furthermore, authors Litwin and $\mathrm{Xu}$ (2007) discovered public areas are often associated with greater clearance 
due to improved visibility. The authors also determined victims found within vehicles were significantly less likely to have their case cleared.

The literature for homicide research examines a broader view of location. Rather than identifying clearance rates for specific locations from the crime scenes, this approach takes into account the community location from which the crime occurred. Incorporating numerous variables, including economic status, area homicide rates and population, in attempts to explore clearances rates from a community perspective.

Area. Research examining economic disadvantage from 1986 to 1995 has shown a significant relationship; indicating areas with lower economic status are at risk of lower clearance rates (Litwin \& Xu, 2007). This finding potentially stems from the culture of the lower socioeconomic neighborhood rather than strain of police resources or devaluation of victims (Kurbin \& Weitzer, 2003). Population size and density produces disputing results regarding their link to clearance rates. One might assume that with larger populations the clearance rate would decrease, but literature failed to show significance when tested against homicide rates (Litwin \& Xu, 2007). Results reject the notion that lower clearance rates are linked to strain from higher detective caseloads. While population size yielded no significance, population density impacted clearance probability (Keel, Jarvis, \& Muirhead, 2009). Again, this is possibly due to the culture of the area studied (Natapoff, 2011).

Time. Time is crucial for homicide investigations; studies consistently show the need for quick response times and utilizing available witnesses and evidence (Carter \& Carter, 2011). Generally, this results in swift clearance, with reports showing about $50 \%$ of homicide arrests seen in 2.6 days and 80\% within 20 days (McEwen \& Regoeczi, 2015). 
Research shows time of day for a homicide's occurrence is not significantly correlated with higher clearances (Regoeczi, Jarvis, \& Riedel, 2008).

\section{Witnesses}

Witness statements. Investigators gather critical information from witnesses at scenes, including motive, location of suspect, identification of suspect and victim, and circumstances surrounding the incident. Factors mentioned, and neighborhood canvassing, are significant clearance predictors for homicide investigations (Baskins \& Sommer, 2010). Identifying and obtaining witness statements before they leave the immediate area is of great importance (Carter \& Carter, 2011). Helping prevent investigators from losing witnesses and gathering the most recent, accurate statements. McEwen and Regoeczi (2015) reported solved homicides average three eyewitnesses and one eyewitness increases case closure by 1.36 , increasing with every available witness. The need for witnesses' statements extends to family members, hospital personnel and follows up interviews (Schroeder and White, 2009).

Essential information is provided through witnesses, and their cooperation remains vital for investigations, regardless of technological advancements. Contexts and incident details assist investigators and witnesses hold the answers for questions. Although a homicide may not produce an eyewitness, producing an incident's context and circumstances may become available through neighbors or family members (Baskin \& Sommers, 2010). Witnesses offer support by explaining possible motives, identifying or locating suspects. "The importance of witnesses cannot be understated" accurately represents the importance of witnesses importance during homicide investigations (Basin \& Sommer, 2010, p. 1,154). 
Community. Lack of trust between community and law enforcement may cause a breakdown in communication, which results in lower clearance rates. Literature shows this distrust extending to witnesses protection agencies as well, revealing the true disconnect between the groups and decreasing clearance rates (Keel, Jarvis, \& Muirhead, 2009). Carter and Carter (2011) discovered neighborhood canvassing and utilizing community-based patrol officers with good rapport with the citizens contributed to successful case outcomes. Furthermore, cities with lower clearance rates are correlated with witnesses and neighborhood trust. For instance, some officers stated that neighborhood canvassing "was a waste of time" and another stated, "the community does not trust us". Crime stoppers or tip hotlines often leads to valuable information. Their usefulness was linked to community's trust with law enforcement, displaying greater value for agencies with better community relations. Community trust is the foundation for many vital investigatory tools, including neighborhood canvassing and anonymous tip methods. Baskins and Sommers (2010) sampled 400 homicide incidents from five jurisdictions (Los Angeles County, California; Indianapolis, Indiana; Evansville, Indiana; Fort Wayne, Indiana; and South Bend, Indiana) from 2003-2006 and reported when witnesses provided information to police arrests, referral, and charges increased significantly. The authors noted a $34.5 \%$ clearance rate and no significance for any forensic evidence, forcing witness information to play a crucial role during the criminal investigation. Furthermore, the authors reported investigation difficulties due to disconnect between community and law enforcement, and reluctance to come forward with information. This is possibly attributable to distrust for law enforcement and fear of retribution (Natapoff, 2011). 


\section{Forensic Evidence}

Clearance value for forensic evidence collected at homicide scenes delivers mixed results for their usefulness. Even the best-equipped crime laboratory and well-trained staff can have limited value for homicide clearances (Carter \& Carter, 2011). McEwen and Regoeczi (2015) examined 294 homicide cases, 315 victims, from 2008 until 2012 in Cleveland, Ohio and found the collection of knives, gunshot residue testing, and clothing at the scene to be significantly related to case closure; however, the forensic evidence only helped clear the case before judicial disposition in 23 of the 151 total closed cases. The collecting of DNA and ballistic evidence were negatively and significantly related to case closures, associated with lower clearance rates. Meaning, forensic evidence was significantly limited during the investigation processes. This is an unsurprising finding and consistent with related forensic evidence studies (Baskins \& Sommers, 2010; Schroeder \& White, 2009). The other categories tested by McEwen and Regoeczi (2015) found no significance, which included latent prints, drugs, trace, electronic, and other tangible evidence. Prior studies find fingerprints as a significant negative predictor to clearance (Schroeder \& White, 2009).

Due to the vast majority of homicides being cleared within 1-2 weeks and forensic evidence testing lasting months, much forensic evidence is only utilized within judicial phases (McEwen \& Regoeczi, 2015; Schroeder \& White, 2009). Similarly, Baskins and Sommers (2010) reported 97\% of homicide incidents had psychical evidence gathered from the crime scene, but at no stage of criminal processing were the forensic evidence significant in solving the homicide. 
DNA collection and testing. Deoxyribonucleic acid (DNA) testing is often viewed as the gold standard of forensic evidence, portrayed as being the most common unbeatable evidence in homicide investigations. DNA is the ultimate genetic indicator for humans and may be extracted from numerous fluids and objects of the human body. While the previous sentences are true, DNA testing is not a fast or simple process and can take several months to accomplish (McEwen \& Regoeczi, 2015; Schroeder \& White, 2009).

Schroeder and White (2009) examined 593 homicides cases that occurred in Manhattan from 1996 until 2003 and concluded "DNA evidence as a tool of last resort". The authors discovered that in $323(54.5 \%)$ cases DNA evidence was never collected, $230(38.8 \%)$ cases had DNA collected and submitted for analysis, and $40(6.7 \%)$ cases had DNA collected, submitted, analyzed and available for the ongoing investigation. Although in 230 cases DNA was collected and submitted, the results were never made available for investigators. Similar to Baskins and Sommer (2010), the authors stated "the results clearly suggest that DNA evidence was largely irrelevant to pre-arrest homicide investigations conducted by the NYPD during the study period." Consistent with McEwen and Regoeczi (2015) was that lower clearances were correlated with DNA evidence collection, testing and availability for investigations. Also, Schroeder and White (2009) noted that of the 40 cases with DNA evidence available for investigators only 11 were cleared.

\section{Investigative Activities}

Strategies. For a four-year period, Carter and Carter (2011) interviewed a diverse number of law enforcement personnel who provided investigatory support. The authors examined four projects and discovered what successfully assisted within the investigation 
process, finding that several approaches and strategies were successful where at least 24 homicides occurred per year in the cities with a median of 36 homicides across the cities included in the analysis. For example, a commonly successful tactic included one supervisor and four investigators, with investigators alternating as leading investigators. A separate approach was a team method, which was uncommon but effective. This method divided the team based on their strengths and allowed them to focus on their skills on each case. However, effectively allocating the officers and discovering strengths was often challenging.

The results above coincide with Keel, Jarvis, and Muirhead (2009), who demonstrate that managerial oversight only marginally improves clearance rates. As with Carter and Carter, results displayed a need for effectively mobilizing and allocating resources.

A primary aspect of these successful approaches was due to time saved with these approaches. Unsuccessful cities commonly scheduled their investigators based on day and evening shifts, ineffectively utilizing investigators and increasing time to crime scenes. Furthermore, officers that responded to the scene first displayed helpfulness when protecting the crime scene and locating witnesses until investigators could arrive. These first responders worked well as supplementary officers until homicide investigators arrived on scene, again proving importance for response time (Carter \& Carter, 2011).

Collaborating with specialized units within their agency and with external agencies significantly increased the likelihood for clearance (Carter \& Carter, 2011). Homicide investigators that did this accomplished a higher clearance rate than those that failed. Working as a team approach with other units and agencies proves to benefit the investigations (Carter \& Carter, 2011). 


\section{Theoretical Framework}

While studies examining correlates of homicide clearance rates by investigators are prevalent in the literature, few studies have applied criminal justice theories to understand police decision making (Higgins, Vito, \& Grossi, 2012; Steffensmeier, Ulmer, Kramer, 1998). The current study seeks to advance the literature by applying Black's theory of moral time to examine the impact of victim-offender relationship on investigative decisions. It is possible that by testing moral time (2011) further explanations into law enforcement decision-making will be available and as to why these decisions are made based on victim/offender relationships, specifically IPH. Thus, a more in-depth discussion of Black's theory is provided below.

Donald Black explains conflict through his theory of moral time (2011), which posits fluctuations and movements in social space are the foundation for all conflict at any given point in time. Aspects, relational time and space, focus on the changes of intimacy amid these relational aspects. The key to understanding these concepts and their subsequent effects on relationships is relational distance, which is the degree of intimacy between individuals. According to Black, any movement in relational space changes the level of intimacy between two or more individuals. If $\mathrm{A}$ increases intimacy with $\mathrm{C}$, then $\mathrm{A}$ decreases intimacy with B; however, though A may decrease intimacy with B, B may still maintain the same levels of intimacy with A. These movements shift the balance of intimacy between persons, and create an imbalance that could lead to conflict. Anytime the intimacy between persons is too imbalanced between persons, overintimacy or underintimacy potentially ensues. Occasions such as these may lead to intimate partner homicides, and greatest social movement in relational space. 
According to Black (2011), relational movements in social space are in flux through social time; therefore, movements of relation space continue during punishments of the offending intimate partner. Meaning, punishments eventuate in social movements. When IPH occur, there are intense movements within social space, especially if incorporating children of the intimate partners. Again, the notion, "If you send my father to prison for killing my mother, for instance, I lose not only my mother but also my father and whatever he contributes to my family and life" (p. 9) is in effect regarding punishments and social movements.

If Black (2011) is correct, due to the degree of social movements resulting from IPH, IPH cases should receive less severe sanctions and sentences. This notion is in effect the antithesis of what one would expect given the relevant literature with respect to homicide investigations and charges. Intimate partner homicides inherently hold strong investigative evidence and relatively high clearance rates, but moral time contends IPH will be adjudicated less severely. To the author's knowledge, there is no existing literature testing moral time's relational time and space against IPH and non-IPH. Although, previous literature does exist that provides evidence of IPH defendants receiving harsher adjudication outcomes (Auerhahn, 2007). The current study uses cross tabulation s to provide a comparison of IPH and non-stranger, testing of moral time's concepts of IPH, and granting insight into law enforcement's decision making in IPH cases. In accordance with Black's theory, the study hypothesizes that IPH will receive more lenient sentence (charge severity and sentence length) than other homicides types. The study also hypothesizes that IPH and non-stranger cases result in less severe 
punishments sought by law enforcement and prosecutors, despite holding greater evidence. 


\section{CHAPTER 3}

\section{METHODOLOGY}

\section{Collection and Analysis}

Researchers began to collect data from closed homicide cases investigated by the Louisville Metropolitan Police Department's Homicide (LMPD) unit in the spring of 2016. Data collection sought to incorporate all pertinent variables within the cases. For the current study, the adjudication process outcomes, relational variables and specific evidence variables examined using cross tabulation.

\section{Data}

Participants. Louisville/Jefferson County, consisting of a population of 736,623, ranks as Kentucky's largest metropolitan area. The homicide unit is divided into three squads, consisting of the homicide squad, cold case squad and missing persons squad. The homicide squad carries the potential for current and future homicide investigations (missing persons suspected of victims of violent crimes), and worked to investigate 60 homicides in 2014, finding some to justifiable homicides of self-defense, and finishing 2014 with a clearance rate of $73 \%$ for criminal homicides. But, this percentage fell to 52\% the following year (2014 Annual Report, 2014). Although LMPD reports their clearance rate to reach the national average in 2014 of $60 \%$ (Carter \& Carter, 2015; Schroeder \& White, 2009), Louisville witnessed a sharp incline in homicides as well as a sharp decline in clearance rates since. The Courier-Journal, for instance, described 84 homicides in 2015 with 54\% of those cases reported closed, and a known stranger committed only five of which (Wolfson, 2016). The changing statistics aforementioned 
means Louisville is currently experiencing changes in the prevalence of homicides and is seeing a reduction in clearance rates.

Sample. The sample includes 68 closed homicide cases investigated by the LMPD homicide unit from 2009 to early 2015. The sample was derived from a list of closed homicides investigated during the seven-year period, excluding open cases from the sample. Cases in the sample differed in their nature and required caution to filter cases that failed to meet study criteria. For instance, often times archives included cases that necessitated death investigation but were not declared homicides. The vast majority of these cases were suicides or accidental deaths, which were initially treated as potential homicides. These preliminary investigations were completed so that no potential homicide was mistakenly deemed suicide or accidental.

Data regarding open cases was denied by LMPD due to the sensitive nature of providing information on open cases. This limited potential analysis and opportunities to compare case correlates between successful and unsuccessful homicide investigations. However, this limitation is one that protects prospective harm to victims and their families.

Data collection. Five separate researchers completed data collection. Data collectors differed greatly in both research experience and law enforcement experience. The experience ranged from thirty plus years law enforcement experience to a decade's worth of policing research experience. Law enforcement knowledge allowed for better data collection from the homicide files. The five researchers double coded the initial ten cases to determine coding accuracy. So, some initial cases were coded at least three times by the research team, and subsequently compared for consistency in coding. Researchers 
concluded the cases contained both consistency and accuracy in coding and collection methods. Once validity was established, collection was assigned to two of the researchers. This, too, contributes to validity by ensuring coding consistency between the two primary data collectors.

The double, sometimes triple, coding methods prevented any differing ideas or inconsistencies in coding variables. The collection method was necessary to prevent any differing discretions, which is critical when determining such aspects as value of evidence within a case. Research validity greatly increased due to these careful coding methods.

The data was collected directly from LMPD's investigation files and allowed for complete examination into the inner workings and details from the homicide investigations. The homicide files were the completed works of lead investigators that incorporated all relevant information from the cases. Case information ranged from interviews, witness statements, crime scene photographs and videos, autopsy report, investigator reports, subpoenas, evidence and crime scene unit report, Kentucky State Police Lab reports, criminal backgrounds, criminal charges, criminal outcomes and all other pertinent investigation information.

Coding instrument. In furtherance of a complete, representative sample, researchers utilized a 27-page instrument that gathered all relevant information, such as individual and social circumstance. As previously mentioned, case files incorporated hundreds of pages of information and researchers designed an instrument thorough and comprehensive data collection and coding. The coding instrument gathered data aimed at collecting virtually all information contained in case files. While much of the information 
was not utilized in the study, it was important for possible future studies and for researchers to learn and work with the data firsthand.

Table 1

Variable Measurements

Variable

Operationalization

Level of Measurement

$\begin{array}{lll}\text { Age } & \text { Age=Years } & \text { Ratio } \\ \text { Gender } & \text { Male, Female, other } & \text { Nominal } \\ \text { Race } & \begin{array}{l}\text { White, Black, Hispanic } \\ \text { Asian, Other } \\ \text { shooter, combatant, } \\ \text { lookout, driver }\end{array} & \text { Nominal } \\ & \text { Nominal } \\ \text { Homicide location } & \begin{array}{l}\text { Where did homicide } \\ \text { occur? }\end{array} & \text { Nominal } \\ \text { Victim/Offender relations } & \begin{array}{l}\text { Social relationship between } \\ \text { victim and offender }\end{array} & \\ \text { History of confrontation } & \begin{array}{l}\text { History of confrontation } \\ \text { Between victim/offender }\end{array} & \text { Nominal } \\ \text { Event to Initiate Incident } & \begin{array}{l}\text { Verbal insult, physical } \\ \text { altercation, weapon brandished, } \\ \text { threat response, other }\end{array} & \text { Nominal } \\ & \begin{array}{l}\text { Suspect, victim, witness, other } \\ \text { unknown }\end{array} & \text { Nominal } \\ \text { Who initiated event? } & \begin{array}{l}\text { Social circumstances } \\ \text { surrounding event }\end{array} & \text { Nominal } \\ \text { What was personal motive? } & \text { Type of weapon used } \\ \text { event? } & \begin{array}{l}\text { Did statements provide } \\ \text { value? }\end{array} & \text { Nominal } \\ \text { Personal motive } & \text { Nominal } \\ \text { Weapon used } & \text { Nominal } \\ \text { Witness statements } & & \end{array}$




$\begin{array}{lll}\text { Phone records } & \begin{array}{l}\text { Did records provide } \\ \text { value? }\end{array} & \text { Nominal } \\ \text { Finger prints } & \text { Finger prints provide Value? } & \text { Nominal } \\ \text { Co-Victim testimony } & \text { Did testimony provide value? } & \text { Nominal } \\ 3^{\text {rd }} \text { Party testimony } & \text { Did } 3^{\text {rd }} \text { party provide value? } & \text { Nominal } \\ \text { DNA } & \text { Did DNA provide value? } & \text { Nominal } \\ \text { Suspect confession } & \begin{array}{l}\text { Did suspect confession } \\ \text { provide value? }\end{array} & \text { Nominal } \\ \text { Vehicle } & \text { Did vehicle provide value? } & \text { Nominal } \\ \text { Gun Shot Residue } & \text { Did GSR provide value? } & \text { Nominal } \\ \text { Body } & \text { Did autopsy provide value? } & \text { Nominal } \\ \text { Anonymous tip } & \text { Did tip provide value? } & \text { Nominal } \\ \text { Cleared exceptionally } & \begin{array}{l}\text { Was homicide cleared } \\ \text { exceptionally? }\end{array} & \text { Nominal }\end{array}$

The coding instrument was designed to collect data regarding all aspects from the homicide investigation, which incorporate individual characteristics (age, gender, race.), situational aspects (social circumstance, motivations, victim/offender relationship), case characteristics (weapon, location), and evidence (DNA, finger prints, phone record). For purposes of clarity, Table 1 operationalizes the variables and data collected in the study. Table 1 displays a condensed version of the over nine hundred variables collected from the coding instrument. The condensed table assists to simplify research by reporting only those variables relevant to the study. For example, some individual characteristics are excluded due to their limited usefulness to the current study.

\section{Variables}


The following discussion described the researcher's decision to exclude and simplify many variables, only utilizing variables that contribute to answer the study's hypotheses and research questions. The reasoning for this decision was to restrict the analysis to variables that directly tested the hypotheses. The study operated two outcome variables to test and determine the first hypothesis: charge severity and sentence length. These dependent and independent variables work best to test and answer the first proposed hypothesis.

Primary outcome variables include sentence length and charge severity, while the study's principal independent variables include homicide type, victim/offender relationship, witness value, DNA value and type of primary weapon. Homicide type and victim/offender relationship worked conjointly as both independent variables and dependent variables, thus enabling the author's examination of situational and evidence variables. The author concluded that applying and measuring these variables would work best to test moral time.

Outcome variables. The outcome variables measure sanction severity by law enforcement and prosecutors. The outcome variables measure sentence length and charge severity to test whether IPH and non-stranger cases hold greater evidentiary value; the current study examined two different outcome variables, which use homicide type and victim offender relationship. These outcome variables were then tested with witness value, DNA value and contact weapon. These dependent and independent variables are the best variables to test and answer the second proposed hypothesis.

The outcome variables are important measures to determine whether specific cases contain innately greater evidentiary value, as proposed in the second hypothesis. The 
evidence selected are recognized to be important evidentiary value for both law enforcement and prosecutors, and known to be common within IPH.

As with homicides themselves, charge and sentences differed greatly; therefore, dichotomous dependent variables were best for statistical analyses. Only the primary charge and associated sentence were analyzed in the study. Primary charges were reduced to homicide and non-homicide charges. With homicide being the most severe, and less severe charges ranged from first-degree manslaughter assault under extreme condition. For sentence length, the variable formed into short and long, using the mean sentence length ( $\mathrm{M}=184.0$ months) to separate the variable into a binary option.

Relational variables. Dichotomous variables were completed for relational variables, also. The study's intimate partner homicide variable necessitated recoding due to high rates of murder/suicide, restricting analyses against independent variables. Instead, IPH was recoded to include expressive homicides, still containing high levels of intimacy (commonly intimate partners, former intimate partners and family members). Expressive homicides were based from circumstances and motives surrounding romance, domestic violence and/or love interest. All other homicides were then recoded as non-expressive homicides. Victim/offender relationship was condensed to stranger and non-stranger homicides. By dichotomizing these variables, the authors could measure intimacy levels against dependent variables and gather evidence variables with clearance.

Evidence variables. Evidence variables, too, were dichotomized, thus simplifying their true effectiveness in homicide cases. DNA evidence and witness statements were further simplified to report their true value for cases. Weapon used was recoded into contact and non-contact in an attempt to compare results to previous findings that contact 
weapons are stronger clearance predictors and commonly associated with IPH. Contact weapons are often considered more intimate weapons and may be associated to more intimate homicides. Dichotomizing independent evidence variables permitted superior analyses against all other previously discussed variables.

\section{Analysis}

The study analyzed the sample population through cross tabulation to present baseline statistics and percent comparison from the homicide case files. The sample size limited statistical power and impending analyses, preventing the researcher from measuring by other statistical means. However, relative to the preponderance of all crimes, the tendency for homicides are rare and study standards resulted in restricted potential cases - 2009-2015 - time frame and access to only closed cases. The majority of desired information was available for collection during the coding process, but occasionally cases failed to report anticipated information. Instances of missing information were often associated with cases involving juvenile victims/offenders and were sanitized of sensitive information. Although sanitized cases limited data collection, the vast majority of necessary information was acquired for the research study.

Cross tabulation analyses were used to compare results of an array of variables, focusing primarily towards social/relational and situational characteristics of the crimes in order to test variables against charge severity and sentence length. Relational/social and situational variables adhere to moral time's existing variables and work to explore under-tested variables associated with sentence length, charge severity and clearance rates. These statistical measures allowed researchers to test the hypotheses for charge severity and produce findings regarding unanswered research questions; are intimate 
partner homicides incorporated with inflating clearance rates? And, whether specific situational homicides produce cases with greater evidentiary value (witnesses, DNA evidence, and contact weapons). 


\section{CHAPTER 4}

\section{RESULTS}

\section{Frequencies}

Data results provide meaningful insights into IPH sanction severity and clearance predictors, along with confirming the evidentiary of many investigative variables. Importantly, the sample allows deeper understandings into relational variables (victim/offender relationship), evidence variables (witness value, DNA value, contact weapon) and their relationships with charge severity and sentence lengths. Furthermore, the data facilitates examination of intimacy's role and interaction with investigative and judiciary processes.

The current thesis hypothesized greater levels of intimacy between victims and offenders would, despite the fact holding greater evidentiary value, result in less severe sanctions and shorted sentences. Frequencies are reported for all relevant outcome and independent variables, and cross tabulation were performed as bivariate analyses to determine the relationships between variables. Some, but limited, support is found for Black's Theory of moral time (2011); although, failing to display a large sample, there may be support for the notion that IPH carrying greater evidentiary value than other homicide types. 
Table 2

Frequency of Dependent Variables

\begin{tabular}{lll}
\hline Variables & $\mathrm{N}$ & Percent \\
\hline Outcome Variables & & \\
Sentence Length & & \\
$\quad$ Short & 15 & 22.1 \\
Long & 10 & 14.7 \\
Valid Total & 25 & 36.8 \\
Missing & 43 & 63.2 \\
$\quad$ Total & 68 & 100.0 \\
Charge Severity & & \\
$\quad$ Homicide & 24 & 35.3 \\
Non-Homicide & 21 & 30.9 \\
$\quad$ Valid Total & 45 & 88.2 \\
Missing & 6 & 11.8 \\
Total & 51 & 100.0 \\
\hline
\end{tabular}

As shown in Table 2, sanction severity proved difficult to produce a substantial sample partly as a result of exceptional clearances (i.e. murder/suicides and justifiable homicides) and a large number of sentencing information missing. This could be due to investigators neglecting to update the file after the case moves to the courts. Overall, the sample size reached a valid total of $\mathrm{N}=25$ after accounting for exceptional clearances and missing data. Short sentences $(x<M=184.0$ months) totaled $N=15(60 \%)$ of valid cases, with long sentences $(x>M=184.0)$ accumulating the remaining $\mathrm{N}=10 \quad(40 \%)$. Charge severity sample reached a valid total of $\mathrm{N}=45$. Homicide charges, the most severe charge, summed $\mathrm{N}=24(53.3 \%)$ of all valid cases, while less severe charges numbered $\mathrm{N}=21$ $(46.7 \%)$ of all valid cases. 
Table 3

\begin{tabular}{|c|c|c|}
\hline Variables & $\mathrm{N}$ & Percent \\
\hline \multicolumn{3}{|l|}{ Independent Variables } \\
\hline \multicolumn{3}{|l|}{ Homicide Type } \\
\hline Expressive & 36 & 52.9 \\
\hline Non-Expressive & 32 & 47.1 \\
\hline Valid Total & 68 & 100.0 \\
\hline \multicolumn{3}{|c|}{ Victim/Offender Relations } \\
\hline Stranger & 8 & 11.8 \\
\hline Non-Stranger & 55 & 80.9 \\
\hline Valid Total & 63 & 92.6 \\
\hline Missing & 5 & 7.3 \\
\hline Total & 68 & 100.0 \\
\hline \multicolumn{3}{|l|}{ Witness Statement Value } \\
\hline Yes & 54 & 79.4 \\
\hline No & 5 & 7.4 \\
\hline Valid Total & 59 & 86.8 \\
\hline Missing & 9 & 13.2 \\
\hline Total & 68 & 100.0 \\
\hline \multicolumn{3}{|l|}{ DNA Evidence Value } \\
\hline Yes & 8 & 11.8 \\
\hline No & 60 & 88.2 \\
\hline Valid Total & 68 & 100.0 \\
\hline \multicolumn{3}{|l|}{ Contact Weapon } \\
\hline Yes & 22 & 32.4 \\
\hline No & 42 & 61.8 \\
\hline Valid Total & 64 & 94.1 \\
\hline Missing & 4 & 5.9 \\
\hline Total & 68 & 100.0 \\
\hline \multicolumn{3}{|l|}{ Cleared Exceptionally } \\
\hline Yes & 20 & 29.4 \\
\hline No & 48 & 70.6 \\
\hline Total & 68 & 100.0 \\
\hline \multicolumn{3}{|l|}{ History of Confrontation } \\
\hline Yes & 42 & 61.8 \\
\hline No & 17 & 25.0 \\
\hline Valid Total & 59 & 86.8 \\
\hline Missing & 9 & 13.2 \\
\hline Total & 68 & 100.0 \\
\hline \multicolumn{3}{|l|}{ Initial Event } \\
\hline Verbal Insult & 14 & 20.6 \\
\hline Physical Altercation & 13 & 19.1 \\
\hline Weapon Brandished & 8 & 11.8 \\
\hline Threat Response & 4 & 5.9 \\
\hline
\end{tabular}




\begin{tabular}{|c|c|c|}
\hline Other & 17 & 25.0 \\
\hline Unknown & 12 & 17.7 \\
\hline Total & 68 & 100.0 \\
\hline \multicolumn{3}{|l|}{ Weapon Type Used } \\
\hline Handgun & 35 & 51.5 \\
\hline Shotgun & 5 & 7.4 \\
\hline Knife & 7 & 10.3 \\
\hline Automobile & 2 & 2.9 \\
\hline Sharp Object & 2 & 2.9 \\
\hline Blunt Object & 7 & 10.3 \\
\hline Hands/Feet & 3 & 4.4 \\
\hline Other & 3 & 4.4 \\
\hline Unknown Weapon & 4 & 5.9 \\
\hline Valid Total & 68 & 100. \\
\hline \multicolumn{3}{|l|}{ Phone Record Value } \\
\hline Yes & 14 & 20.6 \\
\hline No & 22 & 32.4 \\
\hline Total & 36 & 53.0 \\
\hline Missing & 32 & 47.0 \\
\hline Total & 68 & 100.0 \\
\hline \multicolumn{3}{|l|}{ Finger Print Value } \\
\hline Yes & 4 & 5.9 \\
\hline No & 21 & 30.9 \\
\hline Valid Total & 25 & 36.8 \\
\hline Missing & 43 & 63.3 \\
\hline Total & 68 & 100.0 \\
\hline \multicolumn{3}{|c|}{ Co-Victim Testimony Value } \\
\hline Yes & 7 & 10.3 \\
\hline No & 1 & 1.5 \\
\hline Valid Total & 8 & 11.8 \\
\hline Missing & 60 & 88.3 \\
\hline Total & 68 & 100.0 \\
\hline \multicolumn{3}{|c|}{$3^{\text {rd }}$ Party Testimony Value } \\
\hline Yes & 24 & 35.3 \\
\hline No & 6 & 8.8 \\
\hline Valid Total & 30 & 44.1 \\
\hline Missing & 38 & 55.9 \\
\hline Total & 68 & 100.0 \\
\hline \multicolumn{3}{|c|}{ Suspect Confession Value } \\
\hline Yes & 23 & 33.8 \\
\hline No & 1 & 1.5 \\
\hline Valid Total & 24 & 35.3 \\
\hline Missing & 44 & 64.7 \\
\hline Total & 68 & 100.0 \\
\hline \multicolumn{3}{|l|}{ Vehicle Value } \\
\hline Yes & 10 & 14.7 \\
\hline
\end{tabular}




$\begin{array}{lll}\text { No } & 29 & 42.6 \\ \text { Valid Total } & 39 & 57.4 \\ \text { Missing } & 29 & 42.6 \\ \text { Total } & 68 & 100.0 \\ \text { GSR Value } & 3 & \\ \quad \text { Yes } & 19 & 13.4 \\ \text { No } & 22 & 32.4 \\ \text { Valid Total } & 46 & 67.6 \\ \text { Missing } & 68 & 100.0 \\ \quad \text { Total } & & \\ \text { Autopsy Value } & 22 & 32.4 \\ \quad \text { Yes } & 27 & 39.7 \\ \text { No } & 49 & 72.1 \\ \text { Valid Total } & 19 & 27.9 \\ \text { Missing } & 68 & 100.0 \\ \text { Total } & & \\ \text { Victim's Gender } & 30 & 34.5 \\ \text { Female } & 57 & 65.5 \\ \text { Male } & \end{array}$

Frequencies in Table 3 establish counts and percentages for key independent variables and baseline variables to illustrate essential characteristics from the sample, focusing on relational and evidence based variables, as well as others relevant to homicide investigations (weapons and exceptional clearances etc.). The majority of cases resulted in expressive homicides $\mathrm{N}=36$ (52.9\%), leading to $\mathrm{N}=32$ (47.1\%) cases coded as non-expressive homicides. Not surprisingly, non-stranger homicides $\mathrm{N}=55 \quad(80.9 \%)$ dominated the majority of homicides, and only $\mathrm{N}=8(11.8 \%)$ of coded cases were committed by strangers. Above all other evidence, witness statements reported considerably higher levels of value. Fifty-four cases (79.4\%) described witness statements being valuable to the investigation. DNA evidence, though collected at all crime scenes, seldom produced value $\mathrm{N}=8(11.8 \%)$. Contact weapons, known to increase case solvability, were used in $\mathrm{N}=22(32.4 \%)$ of cases. Guns comprised the majority of primary weapons used in 35 cases. As previously mentioned, a sizeable portion of cases 
were classified as exceptionally cleared $\mathrm{N}=20(29.4 \%)$, limiting outcome variable sample size.

Table 4

Cross tabulation for Sentence Length

\begin{tabular}{|c|c|c|c|}
\hline \multirow[t]{2}{*}{ Variables } & \multicolumn{2}{|c|}{ Sentence Length } & \multirow[b]{2}{*}{ Total } \\
\hline & Short & Long & \\
\hline \multicolumn{4}{|l|}{ Relational } \\
\hline \multicolumn{4}{|c|}{ Victim/Offender Relationship } \\
\hline Non-Stranger & $9(47.4 \%)$ & $10(52.6 \%)$ & 19 \\
\hline Stranger $^{\mathrm{a}}$ & $2(100 \%)$ & $0(0.0 \%)$ & 2 \\
\hline Total & $11(52.4 \%)$ & $10(47.6 \%)$ & 21 \\
\hline \multicolumn{4}{|l|}{ Homicide Type } \\
\hline Expressive & $11(84.6 \%)$ & $2(15.4 \%)$ & 13 \\
\hline Non-Expressive & $4(33.3 \%)$ & $8(66.7 \%)$ & 12 \\
\hline Total & $15(60.0 \%)$ & $10(40.0 \%)$ & 25 \\
\hline \multicolumn{4}{|l|}{ Evidence } \\
\hline \multicolumn{4}{|l|}{ Statements Value } \\
\hline Yes & $15(71.4 \%)$ & $6(28.6 \%)$ & 21 \\
\hline No & $0(0.0 \%)$ & $1(100.0 \%)$ & 1 \\
\hline Total & $15(68.2 \%)$ & $7(31.8 \%)$ & 22 \\
\hline \multicolumn{4}{|l|}{ DNA Value } \\
\hline Yes & $1(33.3 \%)$ & $2(66.7 \%)$ & 3 \\
\hline No & $14(63.6 \%)$ & $8(36.4 \%)$ & 22 \\
\hline Total & $15(60.0 \%)$ & $10(40.0 \%)$ & 25 \\
\hline \multicolumn{4}{|l|}{ Contact Weapon } \\
\hline Yes & $7(70.0 \%)$ & $3(30.0 \%)$ & 10 \\
\hline No & $7(50.0 \%)$ & $7(50.0 \%)$ & 14 \\
\hline Total & $14(58.3 \%)$ & $10(41.7 \%)$ & 24 \\
\hline
\end{tabular}

Stranger sample was limited due to exceptional clearances and missing sentencing information within case files

\section{Cross tabulation and Percent Comparisons}

Table 4 presents cross tabulation results for sentence and independent variables. Nonstranger homicides reported slightly higher results for longer sentences, while the two 
stranger cases were reported to have short sentences. Expressive homicides were far more likely to receive shorter, lenient sentences and non-expressive homicides received twice as many longer sentences as they did short. Statement value was displayed more often in shorter sentences, which is probably due to the sample population and that only closed cases with greater evidentiary value were collected. Aligning with prior research, DNA value was slightly more likely to result in a longer sentence, though DNA availability is limited during the investigation stages. Contact weapon was more likely to receive shorter sentences and is possibly a result of the sample population. Contact weapons are used more often during IPH and is potentially why it occurs more often with shorter sentences.

Table 5

Cross tabulation for Charge Severity

\begin{tabular}{llll}
\hline Variables & \multicolumn{2}{c}{ Charge Severity } & \\
& Homicide & Non-Homicide & Total \\
\cline { 2 - 4 } Relational & & & \\
Victim/Offender Relationship & & & \\
$\quad$ Non-Stranger & $20(55.6 \%)$ & $16(44.4 \%)$ & 36 \\
$\quad$ Stranger & $3(60.0 \%)$ & $2(40.0 \%)$ & 5 \\
$\quad$ Total & $23(56.1 \%)$ & $18(43.9 \%)$ & 41 \\
Homicide Type & & & \\
$\quad$ Expressive & $13(48.1 \%)$ & $14(51.9 \%)$ & 27 \\
$\quad$ Non-Expressive & $11(61.1 \%)$ & $7(38.9 \%)$ & 18 \\
$\quad$ Total & $24(53.3 \%)$ & $21(46.7 \%)$ & 45 \\
Evidence & & & \\
Statements Value & & & \\
Yes & $18(47.4 \%)$ & $20(52.6 \%)$ & 38 \\
$\quad$ No & $2(100 \%)$ & $0(0.0 \%)$ & 2 \\
$\quad$ Total & $20(50.0 \%)$ & $20(50.0 \%)$ & 40 \\
DNA Value & & & \\
$\quad$ Yes & $5(62.5 \%)$ & $3(37.5 \%)$ & 8 \\
No & $19(51.4 \%)$ & $18(48.6 \%)$ & 37 \\
$\quad$ Total & $24(53.3 \%)$ & $21(46.7 \%)$ & 45 \\
Contact Weapon & & & \\
$\quad$ Yes & $8(40.0 \%)$ & $10(60.0 \%)$ & 18 \\
No & $14(58.3 \%)$ & $10(55.6 \%)$ & 24 \\
& & &
\end{tabular}


Table 5 exhibits cross tabulation for charge severity, finding non-stranger relationships were given more severe sentences in $\mathrm{N}=20$ (55.6\%) of cases. While Black would expect them to receive more lenient sentences than stranger cases, there were a very small number of stranger cases to compare with. Also, non-stranger cases incorporate varying levels of intimacy and could be a result of the sample population. Expressive, as moral time (2011) argues, received less severe charges than did nonexpressive homicides. Fifty-two percent of expressive homicides received non-homicide charges, while $61.1 \%$ of non-expressive received homicide charges. Witness statement value led to a greater number of non-homicide charges, but is likely a product of the sample population being majority IPH. As with prior research, when DNA evidence was available it led to greater charge severity. Contact weapons received less severe charges, and is possibly due to increased use in IPH and that IPH comprised the sample's majority.

Table 6

Cross tabulation for Victim/Offender Relationship

\begin{tabular}{llll}
\hline Variables & \multicolumn{2}{c}{ Victim Offender/Relationship } & \\
Evidence & Non-Stranger & Stranger & Total \\
\cline { 2 - 4 } $\begin{array}{l}\text { Statements Value } \\
\quad \text { Yes }\end{array}$ & & & \\
$\quad$ No & $43(91.5 \%)$ & $6(85.7 \%)$ & $49(90.7 \%)$ \\
$\quad$ Total & $4(8.5 \%)$ & $1(14.3 \%$ & $5(9.3 \%)$ \\
DNA Value & 47 & 7 & 54 \\
$\quad$ Yes & $7(12.7 \%)$ & $1(12.5 \%)$ & $8(12.7 \%)$ \\
$\quad$ No & $48(87.3 \%)$ & $7(87.5 \%)$ & $55(87.3 \%)$ \\
$\quad$ Total & 55 & 8 & 63 \\
Contact Weapon & & & \\
$\quad$ Yes & $17(32.7 \%)$ & $2(28.6 \%)$ & $19(32.2 \%)$ \\
$\quad$ No & $35(67.3 \%)$ & $5(71.4 \%)$ & $40(67.8 \%)$ \\
& & &
\end{tabular}


Evidence variables were analyzed with victim/offender relationship in Table 6 . This was completed to analyze cross tabulation to find the prevalence of evidence in each relational variable. The small stranger sample size greatly limited testing between the variables. Valuable witness statements reported far large numbers than other variables for both dependent variable categories. Witness statements were valuable in $\mathrm{N}=43(91.5 \%)$ of non-stranger cases, $\mathrm{N}=6(85.7 \%)$ of stranger cases and $\mathrm{N}=49(90.7 \%)$ of all cases examined in Table 6. DNA value provided minimal value and contained value in $\mathrm{N}=7$ $(12.7 \%)$ of non-stranger case, $\mathrm{N}=1(12.5 \%)$ of non-stranger cases and overall $\mathrm{N}=8$ $(12.7 \%)$ of all cases for the victim/offender relationship variable. As expected, contact weapons were used less frequently than non-contact weapons, but were more likely to occur in non-stranger homicides $\mathrm{N}=17$ (32.7\%). Overall, contact weapons were involved in $\mathrm{N}=40(67.8 \%)$ of cases shown in Table 6.

Table 7

Cross tabulation for Victim/Offender Relationship

\begin{tabular}{llll}
\hline Variables & \multicolumn{2}{c}{ Homicide Type } \\
Expressive & Non-Expressive & Total \\
Evidence & & & \\
Statements Value & & & \\
$\quad$ Yes & $30(90.9 \%)$ & $24(92.3 \%)$ & $54(91.5 \%)$ \\
$\quad$ No & $3(9.1 \%)$ & $2(7.7 \%)$ & $5(8.5 \%)$ \\
$\quad$ Total & 33 & 26 & 59 \\
DNA Value & $6(16.7 \%)$ & $2(6.2 \%)$ & $8(11.8 \%)$ \\
Yes & $30(83.3 \%)$ & $30(93.8 \%)$ & $60(88.2 \%)$ \\
No & 36 & 32 & 68 \\
Total & $11(33.3 \%)$ & $11(35.5 \%)$ & $22(34.4 \%)$ \\
Contact Weapon & $22(66.7 \%)$ & $20(64.5 \%)$ & $42(65.6 \%)$ \\
$\quad$ Yes & 33 & 31 & 64 \\
$\quad$ No & &
\end{tabular}


Table 7 illustrates the relationship between evidence variables and homicide type. Cross tabulation allows for frequencies to be shown between the variables. Valuable witness statements comprised the vast majority of expressive $\mathrm{N}=30$ (90.9\%) and nonexpressive homicides $\mathrm{N}=24(92.3 \%)$. The witness statement was of no value in only $\mathrm{N}=5$ (8.5\%) of all expressive and non-expressive cases. In contrast, DNA value was only present in $\mathrm{N}=6(16.7 \%)$ of expressive, $2(6.2 \%)$ of non-expressive homicides, and only valuable in $\mathrm{N}=8(11.8 \%)$ of all homicide type cases. Contact weapons occurred with similar frequency between homicide types and were present in $\mathrm{N}=11(33.3 \%)$ of expressive and 11 (35.5\%) of non-expressive homicides. Contact weapons were used in a total of $\mathrm{N}=22(34.4 \%)$ of cases examined in table 7 .

Cross tabulation and variable frequencies offer notable insights into situational and case characteristics. The study was comprised of mostly IPH and a very limited number of stranger homicides. Expressive received lenient charges and sentences when compared against non-expressive homicides. Non-stranger relationships received a larger number of homicide charges and longer sentences, but we might expect these percentages to be smaller than stranger homicides if a larger sample was available for stranger homicides. Additionally, the findings express the importance of specific evidence and limitations of others. Witness statements proved to be crucial evidence for all relational variables (victim/offender relationship and homicide type), and, in agreement with prior research, DNA evidence was of minimal value during investigations. 


\section{CHAPTER 5}

\section{DISCUSSION}

\section{Introduction}

By utilizing percent comparison, the study displayed that expressive homicide received greater numbers of less severe charges and shorter sentence. Non-expressive homicides were shown to receive more severe charges and longer sentences. Both of these findings are in support of Donald Black's theory of moral time (2011). Evidence variables coincided with past research, finding that witness statements were valuable within the vast majority of cases, DNA evidence produced limited availability but increased charge and sentence, and that guns were the most common weapons used by offender.

\section{Outcome Variables}

Victim/offender relationship. Non-stranger and stranger were done with aims to test a relationship with varying intimacies to one with absolutely no intimacy. The method seemed a logical means to analyze intimacy from a unique spectrum, any level of intimacy (non-stranger) and absolute no intimacy (stranger). Notwithstanding the logic, the sample was too small to accurately measure relationships between victim/offender relationship and outcomes variables using chi-square analysis. In accordance with moral time, if the same sample increased, stranger relationships would certainly represent the most severe charges and longest sentence lengths. With the absence of intimacy within 
the homicides and minimal movement of social space, there would be no motivation to lessen charges or sentence length.

The study reported an overall sample population of $\mathrm{N}=68$, but closed cases for stranger homicide are difficult to gather. The difficulties stem from stranger homicides occurring and being solved at lesser rates compared to other homicides (Baskin \& Sommers, 2010; Roberts, 2007). These facts help to explain why such a smaller stranger homicide sample was seen in the study. The study obtained a much larger sample when examining homicide type.

Homicide type. By breaking down homicide type into expressive and non-expressive homicides, researchers were able to examine IPH against murders involving lesser intimacy from a broad spectrum. It is impossible to measure intimacy levels of different relationships, but it is logical to assume homicides surrounding romantic relationships, domestic violence and/or live interest contain greater intimacy levels than other circumstances (drug/dealer buyer, acquaintance, co-worker). Expressive homicides encompass victim/offender relationships that move beyond intimacy observed in colleagues, business associates or those whom barely know each other. Regardless, love or romantic relationships most commonly involve the highest forms of intimacy. This is largely due to the relationships reaching emotional and sexual elements. Non-expressive homicides cover a broad spectrum and contain varying levels of intimacy, but never reaching levels near expressive.

The fact that expressive homicides receive decreased punishments is a meaningful finding and evidence for Donald Black's theory that homicides with greater intimacy receive lesser punishments. Showing that intimacy may in fact play a role in charges and 
sentencing. The conclusion coincides with prior research and the roles relationships have with charging and sentencing phases. According to Dawson (2004), IPH offenders received not only lighter sentences, but also leniency in charging decisions and types of adjudication.

Expressive homicides received a greater number of shorter sentences than they received less severe charges. One would expect the variable to present an equal number of short sentences and less severe charges since sentences are generally based on the charges. However, this finding is possibly a result of prosecutorial confidence. Prosecutor powers include the ability to select a lighter charge due to varies reasons-generally evidence availability — with expectations that an offender receives the charges maximum sentence, or a sentence close to the maximum (Spohn, Beichner \& Davis-Frenzel, 2001). Rather than increasing charges and elevating burdens to convict the offender, prosecutors often elect lighter charges and aim for eliciting a maximum sentence.

The reasoning above potentially explains the lack of relationship between the victim/offender relationship and offender type with charge severity, but simultaneously explaining why shorter sentence length was present more often in results. Furthermore, in terms of punishments and criminal sanctions, sentence length's consequences outweigh that of charge severity.

Sentence length, one might argue, is of greater importance than charge severity when exploring Donald Black's theory. A homicide charge affects offenders in society through a multitude of ways, but sentence length is the best measure for overall severity. Sentence length determines the length of time an offender is devoid of freedoms and absent from their family members, which, Black would argue, is the primary reason why an IPH 
offender would be sentenced to less time in prison than their counterpart. This reasoning was stated best by Black himself, "If you send my father to prison for killing my mother, for instance, I lose not only my mother but also my father and whatever he contributes to my family and life."

If capable of quantifying intimacy between victim/offenders, increased support for moral time may be found. For instance, expressive and non-expressive, in effect, measures intimacy around basic criteria. Separating expressive homicides (romantic relationship, domestic violence and/or love interest) and non-expressive (any other circumstances and motives). If a scale was available to measure precise intimacy, then a more precise measure of intimacy between variables may be analyzed. The preceding results partially support the hypothesis of Donald Black's theory of moral time, specifically movements of social space in relational time by looking at offender punishment severity (charges and lengths).

Theory. The fact that expressive homicides received decreased punishments compared against non-expressive homicides signifies movements of social space in relational time affects sentence length to an extent. Expressive homicides carry the greatest movements in relational time due to their substantial impacts in social space; thereby, in some manner, influence sentencing decisions for offenders of expressive homicides. Limiting sentence lengths minimizes any further movements of social space in the recently obstructed relational space.

An aspect of moral time speaks about the culmination of conflict and how conflict generates more conflict. The idea of a perpetuation of conflict is stated by Black (2011), "every conflict is itself a movement of social time and every conflict therefore causes 
more conflict" (p. 4). Interestingly, this idea may be evidence within the data given that $71.2 \%$ of homicides reported a history of confrontation between the victim and offender. This is of great evidentiary value because the confrontation presents investigators with a motive and suspect. Both aspects are invaluable for homicide investigators and strong clearance predictors (Baskins \& Sommers, 2010; Litwin \& Yill, 2007; Regoeczi, Jarvis, Riedel, 2008; Schroeder and White, 2009).

\section{Evidentiary Value}

Relational variables. By operating victim/offender relationship and homicide types as dependent variables, the author determined whether certain evidence variables were innately found within specific homicide types and evidence's effect on adjudication processes. Research from McEwen and Regoeczi (2015) indicated forensic evidence increase charge severity and sentence length when available for prosecutors. The current study indicated some, but limited, support when testing whether specific homicides contained stronger evidence. A larger sample population may yield better findings for the notion.

However, though there may be minimal percent comparisons between variables, an answer may be available to explain this lack of support. Current findings fail to compare variables of closed cases with open cases, but the results exemplify patterns in closed case that assisted in clearances. Meaning, since all sample cases are closed, a pattern may be observed with evidence variables across the closed cases.

Evidence variables. From the evidence variables analyzed through cross tabulation-witness statements, DNA value, contact weapon-witness statements reported far greater frequency across all relational variables. No matter the 
victim/offender relationship or homicide type, witness statements proved to be a key clearance predictor. Similar results were observed when viewing frequencies for covictims, $3^{\text {rd }}$ parties, suspect confessions and phone records. "The importance of witnesses cannot be understated" accurately represents witness' importance displayed in the study (Basin \& Sommer, 2010, p. 1,154).

Autopsies, not a primary evidence variable for this study, proved to be the most common clearance indicator for all forensic evidence variables. The other forensic evidence failed to display similar results as strong clearance predictors. Prior research by Carter and Carter (2011) noted the importance and reported medical examiners and autopsies abilities to provide investigators with unique characteristics, manner of death and helpfulness determining the type of homicide.

\section{Intimate Partner Homicide}

As further evidence for IPH holding greater evidentiary value, the study compares IPH of the current study to IPH from a larger, comprehensive study. Comparing the current study with a more comprehensive study grants abilities for deductive reasoning. The Bureau of Justice Statistics (BJS) reports very useful comparison information for IPH spanning nearly three decades from $1980-2008$. According to the BJS, $21.9 \%$ of homicides are stranger homicides, $16.3 \%$ of homicides are IPH and that $77.0 \%$ of homicide victims are male. These numbers are much less than those observed in the current study's sample, which report stranger homicides occurring at $12.7 \%$, IPH homicides at $52.9 \%$ and $65.5 \%$ of victims being male (nine of the male victims are perpetrators of murder/suicide). The overrepresentation of IPH may strengthen support that IPH contain innately valuable clearance predictors in the current sample population. 
The results show that strong evidentiary variables are proportionality found within victim/offender relationship and homicide type. When compared to the BJS's superior sample, the current study exhibits stranger homicides and male victims as underrepresented and IPH as overrepresented. This hints that IPH in the current study's sample population may indeed contain stronger evidentiary value than other homicides. If BJS reports only $16.3 \%$ of homicides as IPH but the current study found over half to be IPH, then there is a reasonable likelihood a majority of IPH are being solved and smaller percentage of other homicides are remaining unsolved. These numbers potentially establish that all cases sampled have greater clearance predictors. And, because IPH is overrepresented, they are more commonly associated with strong clearance predictors. Still, this interpretation cannot be statistically proven with the current sample, and the best means of determining this would be to compare closed and open cases.

Exceptional clearances. The nation's homicide clearance rate is reported at roughly $60 \%$, down from $90 \%$ experienced in the 1960 's. Numbers suggest obvious changes and increasing difficulties in the nature of homicides and their investigations. Clearance numbers are further depressed when examining exceptional clearances. Clearances and exceptional clearances are generally grouped into one statistic, which inflates an agency's overall clearance statistic (Jarvis \& Regoeczi, 2009). The study found N=20 (29.4\%) meet the standards of exceptionally clearances. The majority of these cases were IPH cases.

These statistics are presented to describe clearance rate's true state within the United States, and demonstrate that national average may be well below $60 \%$ when excluding cases involving murder/suicide, justifiable homicide or when circumstances prohibit 
prosecution of suspects. Further studies are needed to better understand and propose solutions to the problem.

\section{Moral Time}

The findings show that IPH homicides did indeed receive lesser sentences. A finding that supports the Theory of moral time and the theory that IPH cause great movements of social space, which then create punishments that cause minimal movements in social space. The marginal results exhibited in analyses suggest other theories may be better applicable to homicide sanctions.

Donald Black's theory of moral time lends a straightforward and simplistic theory into sanction severity, but the theory's simplistic approach may not be best suited for the complex topic of homicide investigations and sanction severity. Homicide investigations

deal with numerous variables that range from situational, individual and evidence based characteristics. All of which hold some level of responsibility within homicide cases. Donald Black's theory excludes the vast majority of these variables. Focal Concerns (Steffensmeier, Ulmer \& Kramer, 1998) takes account the victim/offender relationship and various other aspects.

Steffensmeier, Ulmer and Kramer (1998) base their theory around three focal concerns during judicial decision, blameworthiness of offender, degree of harm caused by the victim and protection of the community. These three focal concerns could encompass the copious variables associated with homicides and may be best suited to answer complicated questions surrounding charge severity and sentencing length.

\section{Limitations}

The small sample size limited statistical analyses and restricted advanced statistical 
measurements. The small sample prevented true measurements of stranger and nonstranger homicides. Homicides that are difficult to collected due to the cases being cleared less often and occurring at lesser rates.

Access to open cases would greatly improve research opportunities for the study by providing a comparison group. Researchers would be capable of examining variables associated between the groups, and test for strong clearance predictors. Having open cases would allow researchers to decide which evidence are commonly missing from open cases and compare the incidents to closed cases.

\section{Summary of Current Study}

The current study sought to improve homicide investigation literature by applying theoretical framework of moral time (2011) and add knowledge to specific homicides and their inherent evidence. Findings from the study lend additional research for IPH, inherent evidence and their relation to the adjudication process.

Partially agreeing with moral time (2011), IPH appeared to receive lesser charges, shorter sentences, and be cleared at higher rates than other homicides. Also, certain variables observed greater investigatory value with increased regularity while others afforded marginal value. The study examined three primary evidence variables and found witness value be common clearance indicators. A finding that coincides with prior research (Baskins \& Sommers, 2010; Litwin \& Yill, 2007; Regoeczi, Jarvis, Riedel, 2008).

The study finds only limited support for both hypotheses, but grants an overview of homicide investigations within Louisville, KY. Facilitating an insightful examination of homicides by reporting on baseline homicide characteristics. The findings dispel general 
misconceptions regarding what indicators and factors clear homicides. The study informs readers about the effects of homicide types on adjudication process and what aspects truly help homicide investigations, such as witness cooperation and community support. The study also displays limited support for DNA and other forensic evidences. 


\section{REFERENCES}

Addington, L. A. (2006). Using national incident-based reporting system murder data to evaluate clearance predictors. Homicide Studies, 10(2), 140-152.

Alderden, M. A., \& Lavery, T. A. (2007). Predicting homicide clearances in Chicago investigating disparities in predictors across different types of homicide.

Homicide Studies, 11(2), 115-132.

Auerhahn, K. (2007). Just another Crime? Examining disparity in homicide sentencing. The Sociological Quarterly, 48(2), 277-313.

Banks, L., Crandall, C., Skylar, D., \& Bauer, M. (2008). A comparison of intimate partner homicide to intimate partner homicide-suicide. Sage, 14(9), 1065-1078.

Baskins, D., \& Sommers, I. (2010). The influence of forensic evidence on the case outcomes of homicide events. Journal of Criminal Justice, 38(6), 1141-1149.

Black, D. (2011). Moral Time. New York, NY: Oxford University Press.

Cardarelli, A., \& Cavanagh, D. (1992). Uncleared homicides in the United States: An exploratory study of trends and patterns. Presentation, New Orleans, FL.

Carter, D., \& Carter, J. (2015, March). Effective police homicide investigations: Evidence from seven cities with high clearance rates. Homicide Studies, 20(2), 127. 
Catalano, S. (2013, November). Intimate partner violence: Attributes of victimization, 1993-2001. In U.S. Department of Justice.

Cook, P. J., Ludwig, J., \& Braga, A. A. (2005). Criminal records of homicide offenders. JAMA: Journal of The American Medical Association, 294(5), 598-601.

Cooper, A., \& Smith, E. L. (2011). Homicide trends in the United States. Washington, D.C: U.S. Bureau of Justice Statistics.

Cooper, A., \& Smith, E. L. (2011, November). Homicide trends in the United States, 1980-2008: Annual rates for 2009 and 2010. In Office of Justice Programs Bureau of Justice Statistics. Retrieved April 8, 2017, from https://www.bjs.gov/content/pub/pdf/htus8008.pdf

Davis, R.,, Jensen, C., Burgette, L.,, \& Burnett, K. (2014). "Working Smarter on Cold Cases: Identifying Factors Associated with Successful Cold Case Investigations." (2014), Journal of Forensic Sciences. 59(2), 375-382.

Dawson, M. (2004). Rethinking the boundaries of intimacy at the end of the century: The role of victim- defendant relationship in criminal justice decision making over time. Law \& Society Review, 38, 105-138.

Demuth, S., \& Steffensmeier, D. (2004). Ethnicity effects on sentence outcomes in large urban courts: Comparisons among white, black, and Hispanic defendants. Social Science Quarterly, 85(4), 994-1011. 
Englich, B., Mussmeiler, T., \& Strack, F. (2006). Playing dice with criminal sentences: The influence of irrelevant anchors on experts' judicial decision making. Society for Personality and Social Psychology, 32(2).

Finkelhor, D., Ormrod, R., \& Humphrey, J. (2001). Homicides of children and youth. In Office of Juvenile Justice and Delinquency Prevention.

Fox, K., \& Allen, T. (2014). Examining the instrumental- expressive continuum of homicides: Incorporating the effects of gender, victim-offender relationships, and weapon choice. Homicide Studies, 18(3), 298-317.

Higgins, G. E., Vito, G. F., \& Grossi, E. L. (2012). The impact of race on the police decision to search during a traffic stop: A focal concerns theory perspective. Journal of Contemporary Criminal justice, 28(2).

Jarvis, J. P., \& Regoeczi, W. C. (2009). Homicide clearances: An analysis of arrest versus exceptional outcomes. Homicide Studies, 13(2). 174-188.

Jensen, V. (2001). Why women kill: Homicide and gender inequality. Boulder, CO: Lynne Rienner.

Keel, T. G., Jarvis, J. P., \& Muirhead, Y. E. (2009, February). An exploratory analysis of factors affecting homicide investigations: Examining the dynamics of murder clearance rates. Homicide Studies, 13(1), 50-68.

Koons-Witt, B. A., Sevigny, E. L., Burrow, J. D., \& Hester, R. (2014). Gender and sentencing outcomes in South Carolina: Examining the interactions with race, age, and offense type. Criminal Justice Policy Review, 25(3), 299-324. 
Kurbin, C., \& Weitzer, R. (2003). Retaliatory homicide: Concentrated disadvantage and neighborhood culture. Social Problems, 50(2), 157-180.

Litwin, K., \& Xu, Y. (2007). The dynamic nature of homicide clearances: A multilevel model comparison of three time periods. Homicide Studies, 11(2), 94-114.

Maher, L., \& Dixon, D. (1999). Policing and public health: Law enforcement and harm minimization in a street-level drug market. The British Journal of Criminology, 39(4), 488-512.

Maxfield, M. (1989). Circumstances in supplementary homicide reports: Variety and validity. Criminology, 27(4), 671-696.

McEwen, T., \& Regoeczi, W. (2015). Forensic evidence in homicide investigations and prosecutions. American Academy Forensic Sciences, 60(5), 1-11.

Natapoff, A. (2011). Snitching: Criminal informants and the erosion of American justice. New York City, NY: New York University Press.

Pratt, T., \& Godsey, T. (2002). Social support and homicide: A cross-national test of an emerging criminological theory. Journal of Criminal Justice, 30(6), 589-601.

Pritchard, C., \& Butler, A. (2003). A comparative study of children and adult homicide rates in the USA and the major western countries 1974-1999: Grounds for concern? Journal of Family Violence, 18(6), 341-350.

Quick Facts (2016). In United States Census Bureau. Retrieved November 15, 2016, from http://www.census.gov/quickfacts/table/PST045215/21111 
Quinet, K., \& Nunn, S. (2014). Establishing the victim-offender relationship of initially unsolved homicides: Partner, family, acquaintance, or stranger? Homicide Studies, 18(3), 271-297.

Regoeczi, W. C., Jarvis, J., \& Riedel, M. (2008). Clearing murders: Is it about time? Journal of Research in Crime and Delinquency, 45(2), 142-162.

Riedel, M., \& Boulahanis, J. (2007). Homicides exceptionally cleared and cleared by arrest: An exploratory study of police/prosecutor outcomes. Homicide Studies, 11(2), 151-164.

Roberts, A. "Predictors of homicide clearance by arrest an event history analysis of NIBRS incidents." (2007, May). Homicide Studies, 11(2), 82-93.

Schroeder, D. A., \& White, M. D. (2009, September). Exploring the use of DNA evidence in homicide investigations. Police Quarterly, 12(3), 319-342.

Simons, D. (1991). Homicide: A year on the killing streets. New York: Oxford University Press.

Spohn, C. (1990). The sentencing decisions of black and white Judges: Expected and unexpected similarities. Law \& Society Review, 24(5), 1197-1216.

Spohn, C., Beichner, D., \& Davis-Frenzel, E. (2001, May). Prosecutorial justifications for sexual assault case rejection: Guarding the "Gateway to Justice." Social Problems, 48(2), 206-235.

Spohn, C., \& Cederblom, J. (1991). Race and disparities in sentencing: Test of the liberation hypothesis. Justice Quarterly, 8(3), 305-328. 
Steffensmeier, D., Ulmer, J., \& Kramer, J. (1998). The interaction of race, gender, and age in criminal sentencing: The punishment cost of being young, black, and male. Criminology, 36(4), 763-798.

Stout, K. D., \& Brown, P. (1995). Legal and social differences between women and men who kill intimate partners. Affilia, 10, 194-205.

Wellford, C., \& Cronin, J. (200). Clearing up homicide clearance rates. National Institute of Justice Journal.

Wolfgang, M. E. (1957). Victim Precipitated Criminal Homicide. Criminal Law, Criminology, and Police Science, 48(1).

Wolfson, A. (2007). Louisville's deadly year: Behind the murders. Courier-Journal. Retrieved from http://www.courierjournal.com/story/news/crime/2016/02/25/louisvilles-deadly-year-behindmurders/80622230/

2014 Annual Report: Chief Steve Conrad (2014). In Louisville Metro Police Department Retrieved November 9, 2016, from https://louisvilleky.gov/sites/default/files/police/sop searchable and reports/lmp d_2014_annual_report-final.pdf 
CURRICULUM VITA

David S. Lapsey Jr.

\section{CONTACT INFORMATION}

Phone- (502)-445-5687

Email-david.lapsey@louisville.edu

\section{EDUCATION}

May 2017 M.A, Criminal Justice, University of Louisville

May 2015 B.A., Criminal Justice and Criminology; Spanish Minor, Indiana

\section{University Southeast}

\section{RESEARCH INTEREST}

Criminal Investigations

Sexuality and Crime

\section{PUBLICATIONS}

\section{Peer-Reviewed Journal Articles}

In Press Tewksbury, Richard, John C. Navarro, \& David Lapsey Jr. Sound of the penis: Secrecy, sex, and stigma. Deviant Behavior.

2017 Tewksbury, Richard \& David Lapsey Jr. Male escorts' construction of the boyfriend experience: How escorts please their clients. International Journal of Sexual Health. (Accepted March 2017). doi:

$10.1080 / 19317611.2017 .1310788$ 
2016 Tewksbury, Richard \& David Lapsey Jr. It’s more than just a big dick:

Desires, experiences, and how male escorts satisfy their customers. Deviant

Behavior. (Accepted October 2016). doi: 10.1080/01639625.2016.1263076

\section{GRANTS}

Internal Grants

2016 Campbell, B.A. (PI) \& David Lapsey Jr. Louisville Metro Police Department Homicide Investigation Project. University of Louisville, Graduate Student Thesis Grants for Research and Creative Activities in the College of Arts and Sciences (Student) (\$811.00).

\section{RESEARCH PROJECTS}

January 2017-Present

Research Assistant: Kentucky Office of the Attorney General

Sexual Assault Forensic Examination (SAFE) Kit Backlog Research Project

(Kentucky Office of the Attorney General Grant No. RFP 040-1700000102)

(University of Louisville Award Total \$49,998.00).

Research Assistant.

\section{CONFERENCE PRESENTATIONS}

2017 Campbell, B.A. \& David Lapsey Jr. Cold case training-from investigation to convictions: Prosecuting sexual assault cold cases. Lexington, KY. (2017)

2016 Lapsey Jr., D. Colombian law enforcement Conference: Managing media and police relations: Louisville, KY. (2016). 